\title{
Pax-5 (BSAP) recruits Ets proto-oncogene family proteins to form functional ternary complexes on a B-cell-specific promoter
}

\author{
Daniel Fitzsimmons, ${ }^{1,2}$ Wendy Hodsdon, ${ }^{1}$ William Wheat, ${ }^{1}$ Sauveur-Michel Maira, ${ }^{3}$ Bohdan \\ Wasylyk, $^{3}$ and James Hagman ${ }^{1,2,4}$ \\ ${ }^{1}$ Division of Basic Immunology, National Jewish Center for Immunology and Respiratory Medicine, Denver, Colorado 80206 \\ USA; ${ }^{2}$ Department of Immunology, University of Colorado Health Sciences Center, Denver, Colorado 80262 USA; ${ }^{3}$ Institut \\ de Génétique et de Biologie Moléculaire et Cellulaire, Illkirch Cedex, France
}

\begin{abstract}
The paired box transcription factor Pax-5 (B-cell-specific activator protein) is a key regulator of lineage-specific gene expression and differentiation in B-lymphocytes. We show that Pax- 5 functions as a cell type-specific docking protein that facilitates binding of the early B-cell-specific $m b-1$ promoter by proteins of the Ets proto-oncogene family. Transcriptional activity of the $m b-1$ promoter in pre-B-cells is critically dependent on binding sites for Pax-5:Ets complexes. Ternary complex assembly requires only the Pax-5 paired box and ETS DNA-binding domains. Mutation of a single base pair in the ternary complex binding site allows for independent binding by Ets proteins but, conversely, inhibits the binding of Pax-5 by itself. Strikingly, the mutation reverses the pattern of complex assembly: Ets proteins recruit Pax -5 to bind the mutated sequence. Recruitment of Net and Elk-1, but not SAP1a, by Pax-5 defines a functional difference between closely related Ets proteins. Replacement of a valine (V68) in the ETS domain of SAP1a by aspartic acid (as found in c-Ets-1, Elk-1, and Net) enhanced ternary complex formation by more than 60 -fold. Together, these observations define novel transcription factor interactions that regulate gene expression in $B$ cells.
\end{abstract}

[Key Words: B-cell-specific ternary complex; Net; Elk-1; SAP1a; mb-1 promoter]

Received May 23, 1996; revised version accepted July 12, 1996.

As a key regulator of early $B$ lymphopoiesis, the role of B-cell-specific activator protein (BSAP) has been studied extensively (reviewed in Busslinger and Urbánek 1995). BSAP was first identified as a DNA-binding activity in nuclear extracts of early B cells, but not from other tissues (Barberis et al. 1990). A role for BSAP as an important regulator of B-cell-specific gene expression was suggested by the identification of potential target genes. Multiple binding sites for BSAP were detected in the promoter and other regions of the CD19 gene, which, like BSAP, is activated early in B lymphopoiesis (Kozmik et al. 1992). In cells representing later stages of B-cell differentiation, BSAP may modulate the function of promoter and enhancer elements that regulate Ig heavy chain gene expression and isotype class switching (Waters et al. 1989; Xu and Stavnezer 1992; Liao et al. 1992; Liao et al. 1994). Down-regulation of BSAP derepresses Ig heavy chain gene $3^{\prime} \alpha$ enhancer function (Singh and Birshtein 1993; Neurath et al. 1994, 1995). Therefore, BSAP may function as an activator or repressor of transcription in different contexts.

${ }^{4}$ Corresponding author.
Cloning of specific cDNAs identified BSAP as the product of the pax-5 gene (Adams et al. 1992), a member of the Pax multigene family (Walther et al. 1991; Asano and Gruss 1992). The Pax family of DNA-binding proteins comprises a set of developmentally important transcription factors defined by the paired box, a DNA-binding motif that is highly conserved in evolution/Chalepakis et al. 1991; Goulding et al. 1991; Treisman et al. 1991). The roles of Pax family proteins as regulators of cellular differentiation is supported by naturally occuring mutations, including the undulated mutations (Pax1), which affect development of the mouse vertebral column (Chalepakis et al. 1991) and thymus (Wallin et al. 1996); abnormalities of neurogenesis $(\mathrm{Pax}-3)$, including the splotch mutations of mice (Epstein et al. 1991), Waardenberg's Syndrome Type I in humans (Baldwin et al. 1992; Tassabehji et al. 1992), and aniridia (Pax-6) in humans and mice (Hill et al. 1991; Ton et al. 1991; Jordan et al. 1992). Pax-6 meets criteria for a master regulator of tissue-specific gene expression, because ectopic expression of the Pax-6/eyeless protein in Drosophila resulted in a striking redirection of cell fates to form eyes in other imaginal tissues (Halder et al. 1995). Other Pax 
genes may also have crucial roles for the specification of cell fates. However, the identification of only a small number of target genes has been an impediment to understanding how Pax proteins regulate pattern formation in different tissues.

Naturally occurring mutations that inactivate the pax-5 gene have not been reported; however, targeted deletion in mice of sequences encoding the $\operatorname{Pax}-5$ paired box resulted in a complete lack of mature B-lymphocytes (Urbánek et al. 1994). B-lineage cells of pax-5 are arrested at an early stage characterized by the partial rearrangement (D-J only) of Ig heavy chain loci and expression of the B-cell surface marker B220 and other markers of early precursor cells. CD19 transcripts were absent from pax-5 $5^{-1-}$ B cells; however, B cells of CD19 knockout mice developed normally and exhibited effects consistent with the role of CD19 as a costimulator of B-cell activation at later stages of differentiation (Engel et al. 1995; Rickert et al. 1995). Therefore, it is likely that other genes required for the progression of early $\mathrm{B}$ cells to later stages of differentiation are regulated by Pax-5.

We and others have shown previously that the $m b-1$ promoter is a target for regulation by early B-ccll-specific transcription factors (Hagman et al. 1991; Travis et al. 1991; Feldhaus et al. 1992). In this report, we show that Pax-5 binds specifically to the $m b-1$ promoter in vitro and recruits Ets family proteins to bind at an adjacent site. The binding of most Ets proteins to this site is undetectable in the absence of Pax -5 binding. The ability of Ets proteins to be recruited by Pax -5 was localized to a specific amino acid of the Ets DNA-binding domain. Analysis of the functional activity of wild-type and mutated $m b-1$ promoters demonstrated the synergistic effects of Pax -5 and Ets proteins for transcription in early $B$ cells. Recruitment of Ets proteins to specific DNA by Pax-5 constitutes an important mechanism for the regulation of gene expression in the B lineage. Moreover, the identification of Ets family proteins as interactive partners of Pax-5 has implications for the regulation of transcription by Pax proteins in other tissues.

\section{Results}

Novel B-cell-specific ternary complexes assemble on the $\mathrm{mb}-1$ promoter

To determine whether Pax-5 binding sites are present in the $m b-1$ promoter, we examined the binding of ${ }^{32} \mathrm{P}$ labeled $m b-1$ promoter sequences by recombinant human Pax-5 translated in vitro or by pre-B-cell nuclear extract proteins in an electrophoretic mobility shift assay (EMSA; Fig. 1). As a control, Pax-5 binding was also examined using a probe that comprises a high-affinity binding site from the CD19 promoter (CD19-1 probe; Kozmik et al. 1992). A single protein-DNA complex was detected using recombinant Pax-5 and either the CD19-1 probe or sequences comprising a short region $1-97$ to -5 9) of the $m b-1$ promoter (Fig. 1). Binding of Pax-5 to the CD19-1 probe was eightfold more efficient relative to

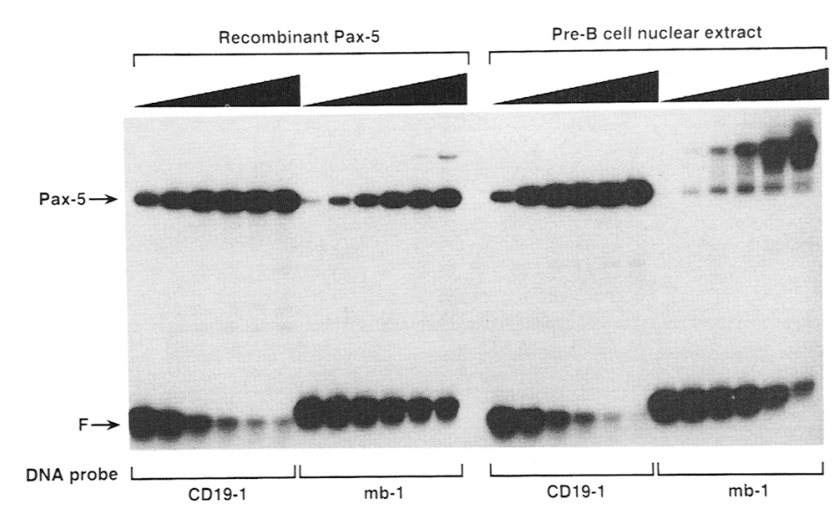

Figure 1. Binding of $m b-1$ promoter sequences by recombinant Pax -5 or pre-B-cell nuclear extract proteins in vitro. ${ }^{32} \mathrm{P}$-labeled double-stranded oligonucleotide probes comprising the high-affinity BSAP binding site of the murine CD19 gene (CD19-1; Kozmik et al. 1992) or sequences of the murine $m b-1$ promoter $(-97$ to -59 ; Travis et al. 1991) were incubated with increasing amounts of recombinant human Pax-5 (left panels) or pre-B-cell $(70 \mathrm{Z} / 3)$ nuclear extract before analysis by electrophoresis through a nondenaturing polyacrylamide gel (EMSA). Complexes formed using recombinant Pax-5 are indicated by the arrow at left. F: Free probe DNA. DNA probes are indicated below. Relative to CD19-1 probe binding, DNA binding of Pax-5 to the $m b-1$ promoter probe is lower by a factor of eight.

the $m b-1$ promoter probe. Similar to the binding obtained with recombinant Pax-5, pre-B-cell nuclear extract proteins assembled one major complex with the CD19-1 probe which comigrated with recombinant Pax-5 complexes. Complexes with similar mobility were observed following incubation of the $m b-1$ promoter probe with pre-B-cell nuclear extracts; however, additional slower migrating complexes were detected that appeared to form at the expense of Pax-5 binding. Low levels of slower migrating complexes were also detected with recombinant Pax -5 and the $m b-1$ probe /attributable to contaminating proteins in reticulocyte lysates; see below $\mid$.

Next, we examined the composition of the $m b-1$ promoter-binding complexes by determining their distribution in various cell types and their relative DNA binding specificities. Four early B-cell-specific complexes were detected using the $m b-1$ promoter probe (Fig. 2, top panel, lane 2) and nuclear extracts derived from $\mathrm{mIg}^{+} \mathrm{B}$ cells, but not from other types of hematopoietic cells or fibroblasts (J. Hagman, unpubl.). Detection of these complexes was paralleled by detection of Pax- 5 binding to the CD19-1 probe (Fig. 2, lower panel). DNA-binding specificities of the early B-cell-specific complexes were determined by incubation of probe DNAs with nuclear extract in the absence or presence of increasing concentrations of unlabeled double-stranded competitor oligonucleotides. Each of the early B-cell-specific complexes was competed by unlabeled $m b-1$ promoter DNA (Fig. 2, lanes 3,4), and more efficiently by high-affinity binding sites for Pax-5 from the CD19 (CD19-1; Fig. 2, lanes 5,6 ) and sea urchin histone $\mathrm{H} 2 \mathrm{~A}-2.2$ promoters (Fig. 
Figure 2. Competitive inhibition of early B-cell-specific complex formation by binding sites for Pax-5 or Ets proteins. Probes were the $m b-1$ promoter or CD19-1 probes described in Fig. 1. Probe DNA was mixed with unlabeled doublestranded competitor oligonucleotides as shown before addition of $0.5 \mu \mathrm{g}$ crude WEHI-231 $\mathrm{mIg}^{+}$B-cell nuclear extract protein. Competitor sequences are described in Materials and Methods.

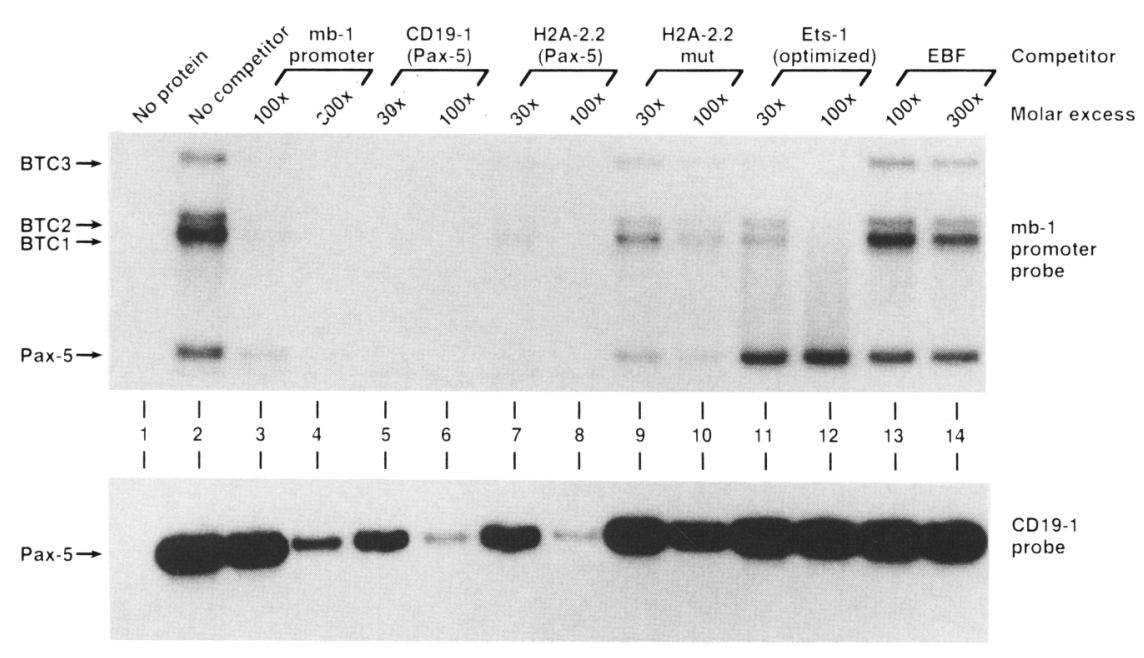

2 , lanes 7,81 . A previously described mutation in the H2A-2.2 site that reduces Pax-5 binding (Barberis et al. 1990) also reduced competition for the early B-cell-specific complexes (Fig. 2, lanes 9,10). A binding site for Early B-cell Factor (EBF) (Fig. 2, lanes 13,14) competed only weakly for DNA binding to either probe.

Our results suggested that Pax-5 is present in each of the early B-cell-specific complexes, but their electrophoretic mobilities indicated the contributions of additional components. Alignment of the $m b-1$ promoter with the recognition sequence of the Ets proto-oncogene family protein Elk-1 (Treisman et al. 1992) identified a highly homologous region adjacent to the Pax-5 binding site lantisense sequence is 5'-GCCGGAGAT; only the underlined base is a mismatch with the Elk-1 consensus). To determine whether Ets family proteins are components of the slower migrating complexes, oligonucleotides comprising an optimized c-Ets-1 binding site were included in the DNA binding assay (Giovane et al. 1994). Significantly, the c-Ets-1 binding site competed for binding by the three slowest complexes, but not for the putative Pax -5 complexes (Fig. 2, lanes 11,12). Binding to the CD19-1 probe was not affected by the c-Ets-1 site competitor. These results imply that Pax -5 can bind the $m b-1$ promoter by itself, or together in ternary complexes with Ets proteins and promoter DNA.

\section{Antisera detect three different Ets proteins in $B$-cell-specific ternary complexes}

To identify components of the B-cell-specific ternary complexes (BTCs) formed using nuclear extracts, we performed a binding assay with the $m b-1$ promoter probe in the presence of specific antisera. Polyclonal antisera raised against the Pax-5 paired box (Fig. 3A, lanes 3,13) or a carboxy-terminal sequence of Pax-5 (Fig. 3A, lane 4) inhibited all specific complexes formed with $\mathrm{mIg}^{+} \mathrm{B}$-cell or pre-B-cell nuclear extracts. More selective effects were obtained with antisera that recognize Ets proteins. A polyclonal antisera recognizing c-Ets-1 inhibited BTC2 binding completely, and reduced BTC1 binding (Fig. 3A, lane 51 . Inhibition of BTC3 complex formation by another specific antisera indicated the presence of the Ets protein GA binding protein $\alpha$ (GABP $\alpha$ ) (Fig. 3A, lane 6). BTC3 complexes were inhibited and supershifted by a second antiserum raised against the Notch-related protein GABPB (Fig. 3A, lane 7), which does not bind DNA by itself, but enhances DNA binding by GABP $\alpha$ (Thomp-

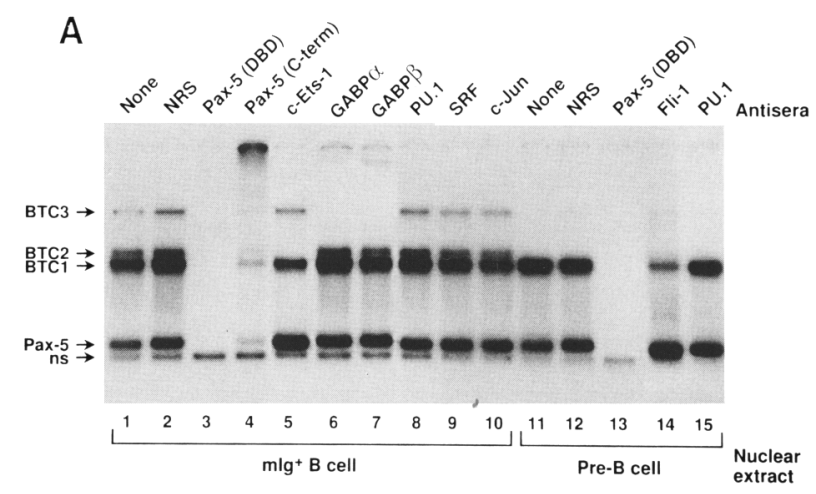

B

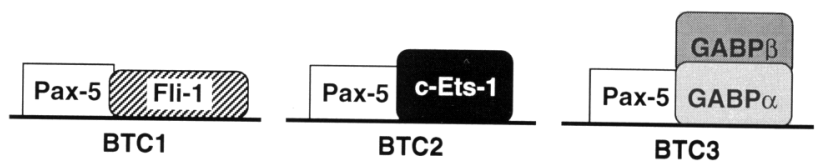

Figure 3. Specific antisera detect Pax-5 and three different Ets proteins in early B-cell-specific complexes. $(A)$ Immunodetection assay. EMSA was performed using the $m b-1$ promoter probe as in Fig. 1, except that nuclear extracts were preincubated without or with normal rabbit serum (NRS) or antisera as shown above prior to addition of probe DNA. Nuclear extracts were prepared from either WEHI-231 $\left(\mathrm{mIg}^{+} \mathrm{B}\right)$ or $70 \mathrm{Z} / 3$ (pre-B) cells. The $70 \mathrm{Z} / 3$ nuclear extract contains very low levels of BTC2 and BTC 3 binding activity. Sera or purified IgG fractions were each added at a final dilution of 1:50. Pax-5 antisera are specific for the paired domain DNA-binding domain (DBD) or the carboxyl terminus (C-term). ns- non-specific complex. $(B)$ Predicted composition of ternary complexes detected using nuclear extracts. Actual stoichiometry of BTC3 is unknown. 
son et al. 1991; Brown and McKnight 1992). Other complexes were not affected by either GABP antisera. Binding of BTC1 assembled using a pre-B-cell nuclear extract 170Z/3 extract, which contains low, but detectable levels of BTC2 and BTC3; J. Hagman, unpubl.) was decreased by $>70 \%$ in the presence of an antipeptide antisera raised against the Ets protein Fli-1 (Fig. 3A, lane 14). As described above, BTCl binding was also decreased by the anti-cEts-1 serum. This may be attributable to cross-reactivity of the antisera with Fli-1. Alternatively, a ternary complex including Pax -5 and a proteolytic fragment of c-Ets-1 may comigrate with BTC1, but the combination of anti-c-Ets-1 and Fli-1 antisera did not reduce BTC1 binding further than did anti-Fli-1 antiserum alone (J. Hagman, unpubl.). Detection of the complexes was not affected by antisera recognizing the Ets proteins PU.1 (Fig. 3A, lanes 8,15), Elk-1, or Net (J. Hagman, unpubl.), or other proteins that reportedly interact with Ets proteins, including Serum Response Factor (Hipskind et al. 1991; Dalton and Treisman 1992) or c-Jun (Bassuk and Leiden 1995; Fig. 3A, lanes 9,10, respectively). The presence of Ets proteins together with Pax-5 in BTCs explains the detection of slower migrating complexes using recombinant Pax-5 (Fig. 1), because reticulocyte lysates are often contaminated with low levels of nuclear proteins, including Fli-1 (J. Hagman, unpubl.). Together, these experiments confirm that BTCs are complexes of Pax-5 together with different Ets proteins (Fig. 3B), including Fli-1, c-Ets-1, or GABP $\alpha$.

\section{Nucleotide sequence requirements for Pax-5 and Ets binding in vitro and functional activity in transfected cells}

A regulatory role for Pax-5:Ets complexes was confirmed by analyzing the effects of mutations on $m b-1$ promoter function in transfected pre-B cells. The first mutation (mut1, Fig. 4A) changed two base pairs of the Ets site core sequence (GGA; Karim et al. 1990; Nye et al. 1992). The second mutation (mut2) changed three base pairs identified as specific contacts for Pax-5 binding in a methylation interference assay (J. Hagman, unpubl.). Oligonucleotides comprising wild-type, mut1, or mut 2 sequences were tested for binding by $\mathrm{mIg}^{+} \mathrm{B}$-cell nuclear extract proteins. Mutation of the Ets site core sequence in the mut1 probe (Fig. 4B, lane 2) resulted in selective loss of ternary complexes, but Pax- 5 complexes were unaffected. Mutation of Pax -5 contacts alone, or together
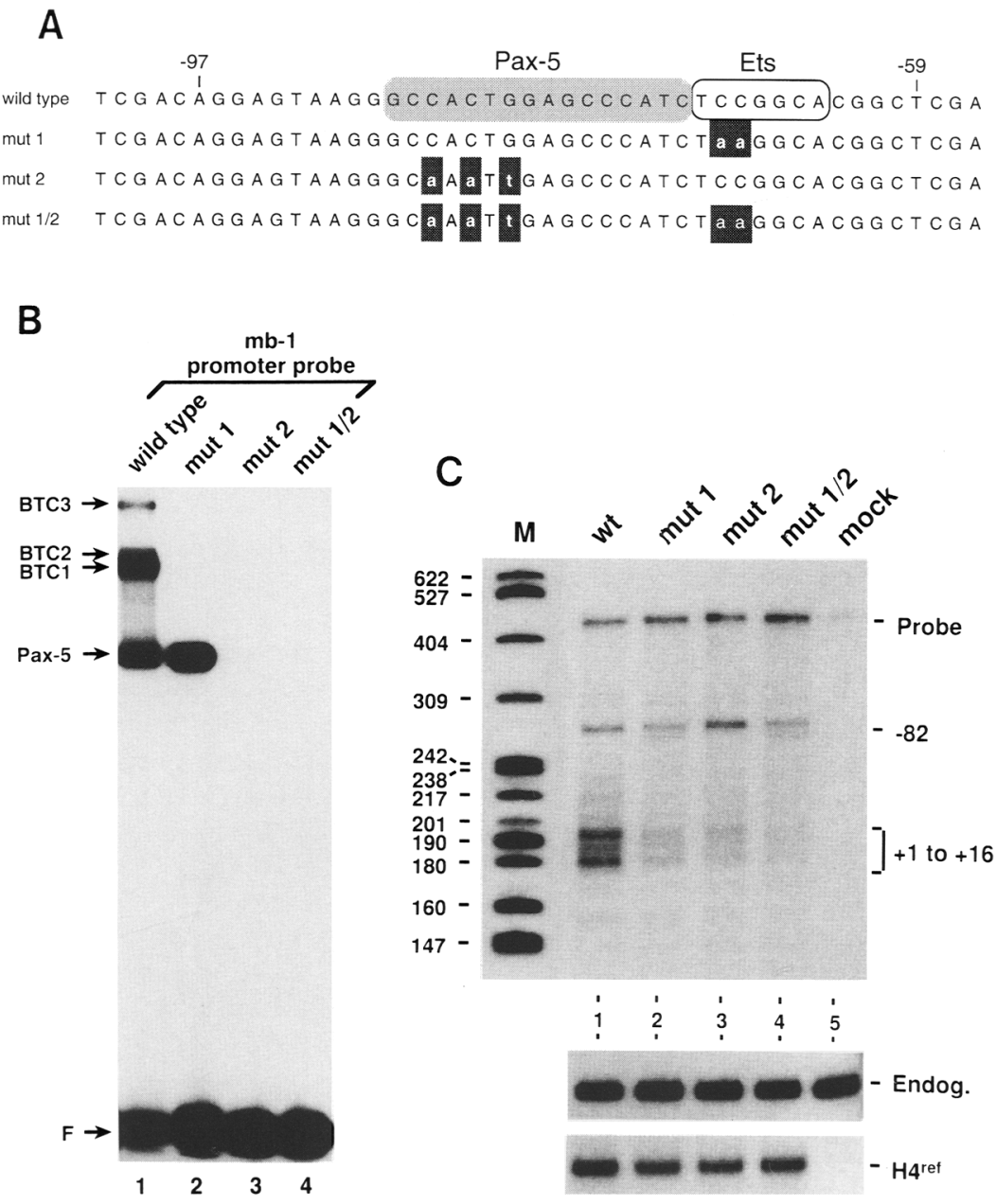

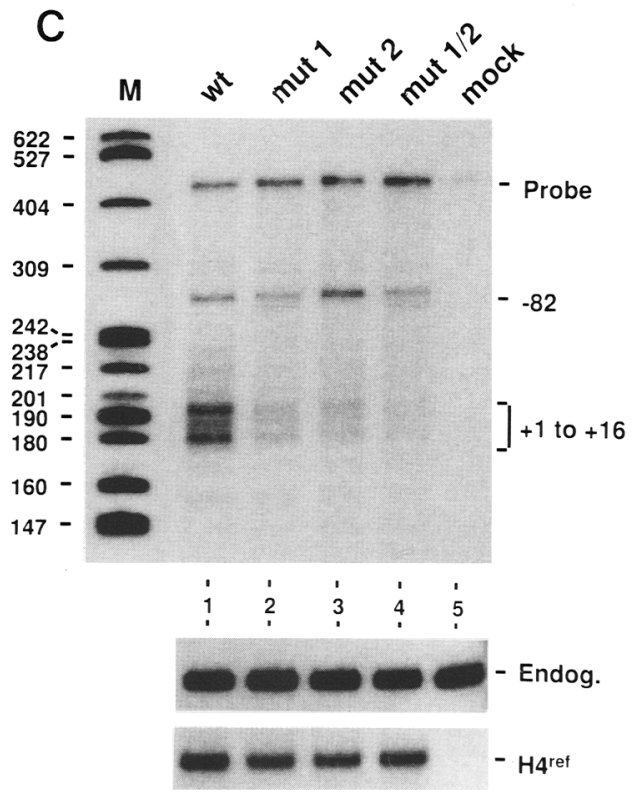

Figure 4. Binding sites for Pax -5 and Ets proteins are required for efficient $m b-1$ promoter function in transfected pre-B-cells. (A) Nucleotide sequences of synthetic oligonucleotide probes used in $B$. Mutations (mut1 and mut2) are shown relative to approximate binding sites for Pax-5 and Ets proteins as determined by methylation interference and DNaseI protection assays (J. Hagman, unpubl.). (B) Binding of $\mathrm{mIg}^{+}$B-cell nuclear extract (WEHI-231) proteins to labeled BTC site probes shown in $A$. EMSA was performed as in Fig. 1. F: free probe. $(C)$ Functional analysis of the effects of Pax-5 or Ets site mutations on $m b-1$ promoter activity. Wild-type $(w t)$ or mutated $m b-1$ promoter fragments $(-252$ to +70$)$ were tested in the plasmid T $\beta P y$ (see Materials and Methods), which comprises a $\beta$-globin reporter gene linked to the promoter, a truncated histone $\mathrm{H} 4$ reference gene for monitoring transfection efficiency, and the polyomavirus origin of replication (Grosschedl and Baltimore 1985). Plasmids were introduced into the pre-B-cell line PD36 using DEAE-dextran-mediated transfection, and total cellular RNA was analyzed for correctly initiated $m b-1$ promoter $(+1$ to +16$)$, reference histone $\mathrm{H} 4$ transcripts $\left(\mathrm{H} 4^{\text {ref }}\right)$, or endogenous histone $\mathrm{H} 4$ (Endog.) using 5 '-end labeled single-stranded DNA probes in an S1 nuclease protection assay. Transcripts originating from an upstream initiation site $(-82)$ in the $m b-1$ promoter (Hagman et al. 1991; Feldhaus et al. 1992) were also detected. As a control, PD 36 cells were treated with DEAEdextran in parallel without plasmid DNA (mock). $\mathrm{M}:{ }^{32}$ P-labeled pBR322 MspI digest size marker. Quantitation was performed using a Molecular Dynamics PhosphorImager. 
with the Ets site core sequence, eliminated nearly all detectable DNA binding to the mut 2 or mut $1 / 2$ probes (Fig. 4B, lanes 3,4).

Effects of mutations on $m b-1$ promoter function were examined by replacement of wild-type sequences with mutated $m b-1$ promoter fragments $(-252$ to +70$)$ in the $m b-1$ promoter/reporter plasmid TMßPy for transfection into pre-B cells (Hagman et al. 1991). Specific transcripts from the reporter and control plasmids were detected using sensitive S1 nuclease protection assays. As reported previously, transcripts from the wild-type promoter initiated most frequently from a cluster of sites $(+1$ to +16$)$, and to a lesser degree from upstream $(\sim-82)$ sites (Fig. 4C, lane 1; Hagman et al. 1991; Travis et al. 1991; Feldhaus et al. 1992). Mutation of either the Ets core sequence (mutl; Fig. 4C, lane 2) or the Pax-5 binding site (mut2; Fig. 4C, lane 3) decreased levels of specific mRNA initiated from downstream sites $1+1$ to +16 ) by $\sim 80 \%$, and the presence of both mutations together decreased transcription by $90 \%$ (mut 1/2; Fig. 4C, lane 4). These results demonstrate that the Pax-5 and Ets binding sites are essential for high level $m b-1$ promoter transcription. Interestingly, transcription from upstream $(-82)$ sites was relatively unaffected by these mutations (mut2 increased -82 transcripts twofold), suggesting that initiation site utilization is differentially regulated.

Assembly of B-cell-specific ternary complexes in vitro is a function of the Pax-5 paired box and ETS DNA-binding domains

Inhibition of DNA binding by antisera determined that Pax-5 and at least three Ets family proteins are present in BTCs assembled using nuclear extracts. To examine whether recruitment by Pax -5 is a general property of Ets proteins, we examined the ability of recombinant Ets proteins to bind the $m b-1$ promoter probe in the absence or presence of Pax-5 (Fig. 5, left panel). DNA binding by Net (also known as ERP, Lopez et al. 1994; or SAP-2, Price et al. 1995), Elk-1, or c-Ets-1 was not observed in the absence of Pax-5 (Fig. 5, lanes 3,5,9). However, detection of complexes with slower mobility indicated that Net, Elk-1, and c-Ets-1 are recruited efficiently (by greater than 100-fold) to DNA by Pax-5 (Fig. 5, lane 2 vs. $4,6,10)$. Strikingly, SAP1a was not recruited to the promoter by Pax-5 (Fig. 5, lane 8), even though its DNAbinding domain is highly homologous to those of Elk-1 $(78 \%)$ and Net $(79 \%)$. In further contrast, SAP1a bound significantly by itself to the $m b-1$ promoter probe (Fig. 5 , lane 7). As a control for functional DNA binding, all four Ets proteins bound efficiently to the Ets-1 probe (Fig. 5, lanes 11-15). Together, these data show that Ets proteins can be divided into two groups based on their ability (e.g., Elk-1) or inability (SAPla) to be recruited to the $m b-1$ promoter by Pax-5. Moreover, recruitment by Pax-5 defines a significant difference between the functional properties of SAP1a and other members of the ternary complex factor (TCF) subfamily of Ets proteins (i.e., Elk-1 and Net).
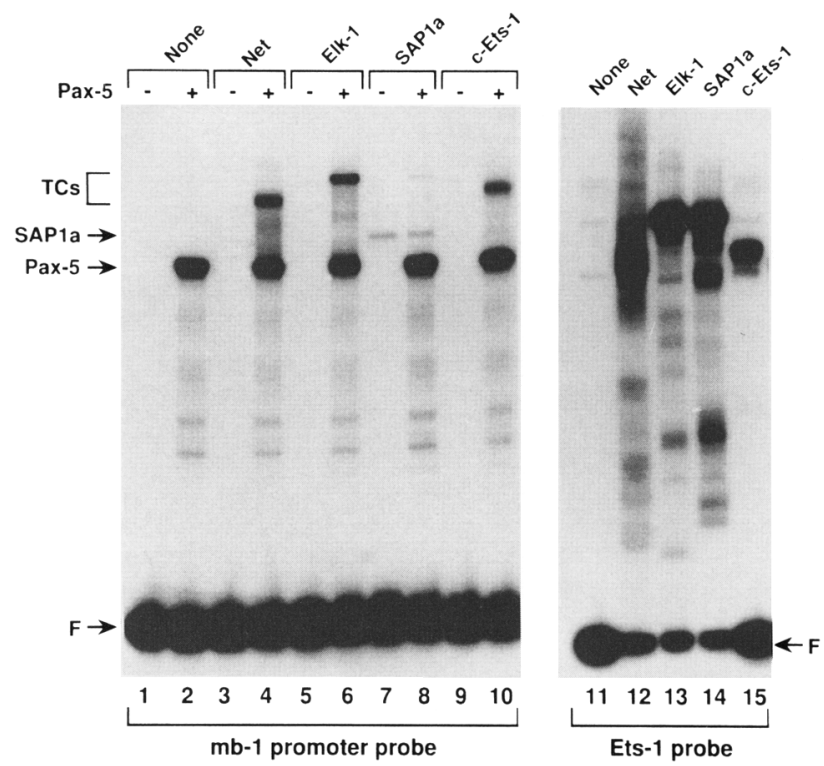

Figure 5. Pax -5 recruits recombinant Ets proteins to bind the $m b-1$ promoter. Recombinant proteins were made by programming rabbit reticulocyte lysates with RNA transcribed from plasmid DNAs using T7 RNA polymerase in vitro (Hagman and Grossched1 1992). Plasmids for expression of full-length human Net (1-409), human Elk-1(1-428), human SAPla $(1-431)$, or murine c-Ets-1 (p50; 1-440) were described previously (Hagman and Grosschedl 1992; Giovane et al. 1994). Translation in the presence of $\left[{ }^{35} \mathrm{~S}\right]$ methionine showed that translation occurred at comparable levels, except c-Ets-1, which was synthesized at approximately one-third the level of the others (J. Hagman, unpubl.). DNA binding by Pax-5 or Ets proteins was examined separately or together. Programmed lysates were combined in binding buffer prior to the addition of probe DNA. (Left) DNA binding to the $m b-1$ promoter probe by Ets proteins in the absence $(-)$ or presence $(+)$ of Pax-5. Positions of Pax-5, SAPla, or ternary complexes (TCs) are indicated at left. (Right) Optimized c-Ets-1 binding site probe (Ets-1 probe). Ets proteins were added to the Ets-l probe at the same concentrations as with the $m b-1$ promoter probe. F: free probe.

The recruitment of members of different Ets subfamilies suggested the interaction of a common structural motif with Pax-5. To localize the interactive domains of these proteins, we synthesized recombinant polypeptides representing full-length or progressively larger carboxy-terminal truncations of Pax-5 and the Ets protein Net. Efficient binding of full-length and truncated Net polypeptides to the promoter was observed only in association with Pax-5 (Fig. 6A, lanes 3-10). As described previously for Net binding to other sequences (Giovane et al. 1994; Lopez et al. 1994; Price et al. 1995), carboxyterminal deletions [e.g., deletions in Net(1-152), Net(1132) and Net(1-89)] allowed for low levels of DNA binding by Net polypeptides alone (Fig. 6A, lanes 11,13,15), but binding was greatly increased by interaction with Pax-5. Notably, full-length Pax-5 assembled complexes efficiently with the most complete truncation (1-89) (Fig. 6A, lane 16), which comprises the minimal ETS DNA-binding domain of Net /the ternary complex nearly 
A

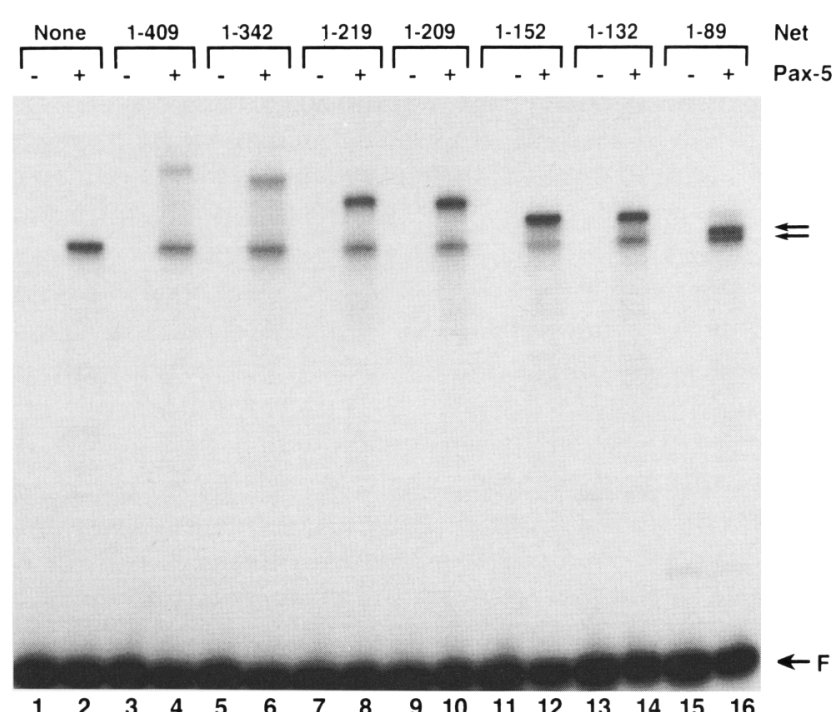

B

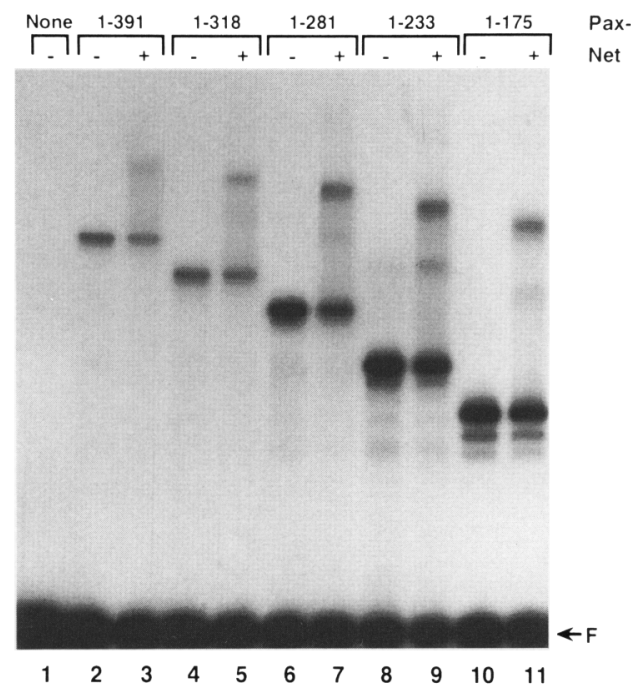

C

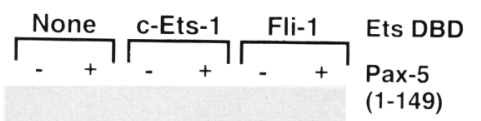
(1-149)

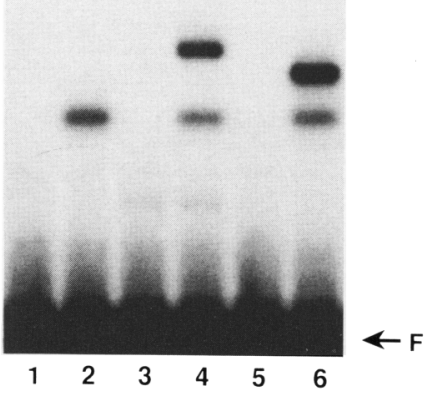

Figure 6. Interaction of Pax-5 and Ets proteins is a function of their respective DNA-binding domains. All polypeptides (described in Materials and Methods) were synthesized using synthetic RNA and rabbit reticulocyte lysates and combined just prior to addition of probe DNA for analysis by EMSA (as in Fig. 5). (A) Recruitment of carboxy-terminal truncations of the Ets protein Net by fulllength Pax-5. Net(1-89) forms a ternary complex that nearly comigrates with full-length Pax-5. A less abundant, slower migrating complex is also detected that may include a dimer of Net. Arrows indicate Pax5:Net $(1-89)$ and Pax-5 complexes lupper and lower arrows, respectively). (B) Recruitment of full-length Net by carboxy-terminal truncations of Pax-5. (C) Minimum requirements for DNA binding by Pax-5 and Ets proteins. DNA binding by Pax-5|1149) is shown in the absence or presence of the ETS domain of either c-Ets-1(333 to 420$)$ or Fli-1/279 to 366). F: free probe. comigrates with Pax-5 complexes|. Therefore, the interaction of Pax-5 with Net is a function of its ETS domain, which is highly conserved between Ets family members (>59\% identity with c-Ets-1; Wasylyk et al. 1993). Furthermore, sequences required for other protein-protein interactions involving Net (e.g., the B domain, which is required for efficient binding of Net with SRF; Giovane et al. 1994) are not required for interactions with Pax-5.

To localize the region of Pax-5 that interacts with Ets proteins, DNA binding by full-length and truncated Pax-5 polypeptides was examined in the absence or presence of Net(1-409) (Fig. 6B). All truncations of Pax-5 bound the $m b-1$ promoter sequence both in the absence of Net or as ternary complexes with Net $(1-409)$. Efficient DNA binding was observed for Pax-5(1-149), which comprises little more than the paired box (Fig. 6C, lane 2). To confirm the minimal requirements for Pax5:Ets ternary complex formation, we combined Pax-5(1149) with the minimal DNA-binding domains of either
c-Ets-1 (333-420) or Fli-1 (279-366). DNA binding by the c-Ets-1 ETS domain was detected weakly in the absence of Pax-5(1-149) (Fig. 6C, lanes 3), and was recruited efficiently by Pax-5(1-149) (Fig. 6C, lane 4). Similar data was obtained with the Fli-1 ETS domain (binding by the Fli-1 DNA-binding domain by itself was visible in longer exposures; J. Hagman, unpubl.) (Fig. 6C, lanes 5,6). DNA binding by Pax-5(1-149) and the ETS domains is cooperative, because the observed level of ternary complex binding exceeded the combined binding of the Pax-5 and ETS proteins by themselves (e.g., in Fig. 6C, total binding in lane 6 vs. sum of lanes 2,5). Together, these data show that the Pax -5 paired box and ETS domains are sufficient for ternary complex formation.

The stoichiometry of component proteins in BTCs was addressed using polypeptides of different lengths. As shown above, DNA binding by full-length Pax-5 (Fig. 7A, lane 2) or Pax-5 (1-149) (Fig. 7A, lane 4) was detected as a single bandshift using EMSA. When the two Pax-5 

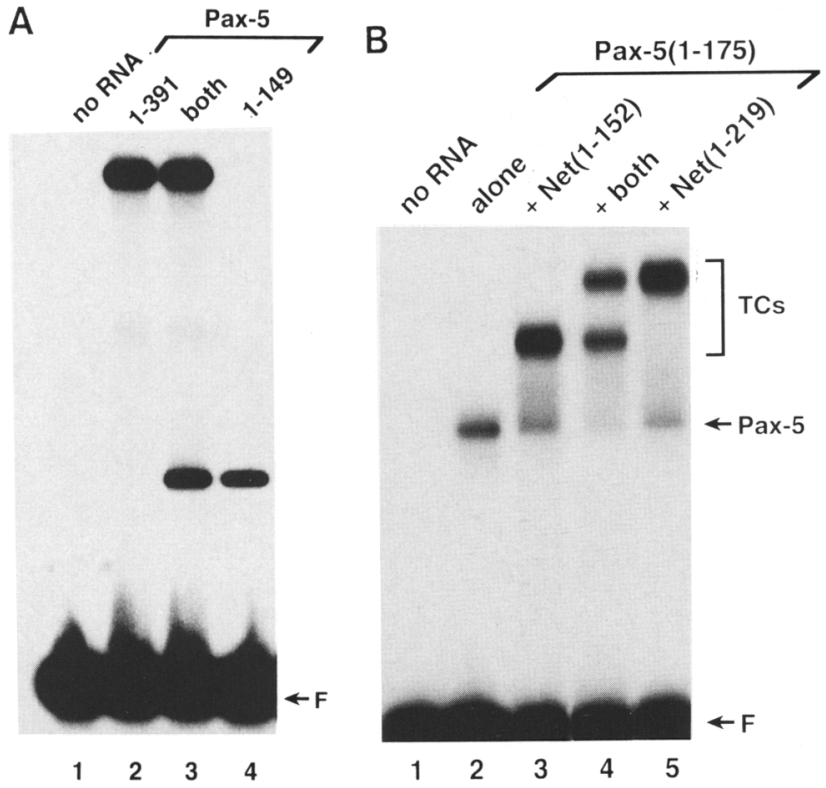

Figure 7. Stoichiometry of Pax-5:DNA and Pax-5:Net:DNA complexes. All polypeptides /described in Materials and Methods) were synthesized using synthetic RNA and rabbit reticulocyte lysates and combined just prior to addition of probe DNA for analysis by EMSA (as in Fig. 5). (A) Pax-5 binds the $m b-1$ promoter sequence as a monomer. DNA binding by Pax-5(1409) or Pax-5(1-149), separately, or mixed following their translation in vitro. $(B)$ Net is recruited as a monomer by Pax-5 to form ternary complexes. DNA binding by Pax-5(1-175) in the presence of Net(1-219), Net(1-152), or both, mixed following translation in vitro.

polypeptides were combined prior to the addition of labeled probe DNA and analyzed using EMSA, the pattern of DNA binding suggested only the binding of Pax-5 monomers, because additional complexes with intermediate mobilities (representing heteromultimers) were not observed. Similarly, we incubated Net(1-219) or Net(1152), separately or together, with Pax-5(1-175) prior to addition of labeled probe. The resulting EMSA patterns included complexes that comigrated with those formed with Pax-5 and either Net polypeptide, but new complexes with intermediate mobilities were not detected (Fig. 7B, lane 4). Similar data were obtained using c-Ets-1 polypeptides (J. Hagman, unpubl.). We conclude that Pax-5:Ets complexes are assembled by recruitment of a single Ets polypeptide by a single Pax- 5 polypeptide (except for BTC3, which comprises Pax-5, GABP $\alpha$, and GABPß).

A single base-pair mutation in the mb-1 promoter binding site reverses requirements for ternary complex formation

In Figure 4B, we showed that the Ets core sequence GGA is essential for the assembly of Pax-5:Ets ternary complexes. The context of this sequence in the $m b-1$ promoter is unusual, because the $G$ nucleotide $1-71$ in Fig.
4A) adjacent to the Ets binding site core sequence (GGA on the antisense strand) has not been observed in other naturally occuring Ets binding sites (Wasylyk et al. 1993). Instead, the sequence at this position is generally an $\mathrm{A}$ or $\mathrm{T}$ nucleotide. To address further the nucleotide sequence requirements for ternary complex formation by Pax -5 and Ets proteins, we mutated the last $G$ nucleotide of the sequence $5^{\prime}$-CCGGAG to an $\mathrm{A}$ in the context of the mb-l promoter probe $(\overline{\mathrm{G}}$ to $\mathrm{A}$ mutation probe) for analysis of binding using EMSA. As shown in other experiments, Pax-5(1-175) bound the ${ }^{32}$ P-labeled wild-type mb-1 promoter probe by itself (Fig. 8, lane 2) and assembled ternary complexes with Net(1-219) (Fig. 8, lane 4). Net(1-219) did not bind the probe in the absence of Pax5(1-175). As expected, optimization of the Ets binding site in the $G$ to A mutation probe greatly enhanced the binding of Net(1-219) by itself (Fig. 8, lane 7). Conversely, Pax-5(1-175) binding was reduced by the $\mathrm{G}$ to $\mathrm{A}$ mutation to $\sim 5 \%$ of binding to the wild-type sequence. We conclude that the $\mathrm{G}-\mathrm{C}$ base pair adjacent to the Ets core sequence includes important contacts for Pax-5 binding. However, the combination of Pax-5(1-175) and Net(1-219) with the mutated probe resulted in additional complexes which comigrated with the Pax-5:Net complexes observed with the wild-type probe (although at one-fourth the level of binding; lane 8 vs. lane 4). Similar results were obtained using intact Pax-5 and Ets proteins from early B-cell nuclear extracts. Binding of intact Pax-5 to the G to A mutation probe was reduced to very low levels, but BTCl complexes (Pax-5:Fli-1) were

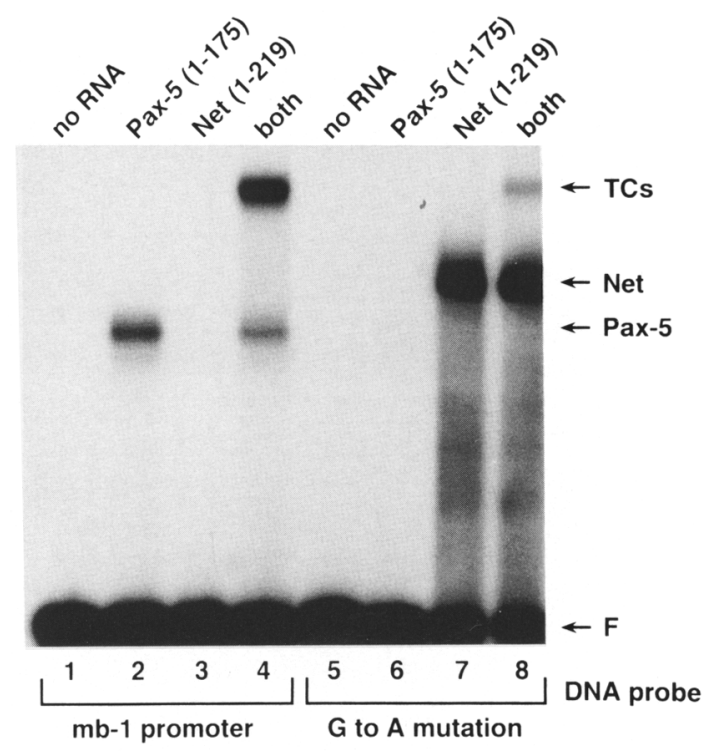

Figure 8. A single $\mathrm{G}$ to $\mathrm{A}$ mutation in the $m b-1$ promoter Pax-5:Ets binding site $(-71$ on the antisense strand) inhibits Pax-5 and enhances Net binding, and Net recruits Pax -5 to bind the mutated sequence. Polypeptides were synthesized in vitro and included in binding reactions as indicated above. EMSA was performed as in Fig. 7. Probe DNAs are indicated below. Polypeptides in complexes are indicated at right. TCs: ternary complexes. 
detected at similar levels relative to the wild-type sequence (D. Fitzsimmons, unpubl.). Therefore, a single base change in the Pax-5:Ets binding site allows ternary complexes to assemble in a reciprocal fashion relative to the wild-type binding site.

\section{A single amino acid change in SAP1 a allows for recruitment by Pax-5}

Although binding of the $m b-1$ promoter by most Ets family polypeptides was increased by association with Pax-5, SAPla was a notable exception. Alignment of the amino acid sequences of ETS domains (Fig. 9A) identified three amino acids in SAP1a (black shading; K17 was analyzed together with $\mathrm{P} 18$ ) that are conserved as a significantly different amino acid among Ets proteins that are efficiently recruited by Pax-5 (Fli-1, c-Ets-1, GABP $\alpha$, Net, and Elk-1). To address whether any of the sequences govern interactions with Pax-5, we mutated sequences of SAPla to match those of Elk-1 and examined the ability of the mutated protcins to be recruited to DNA by Pax5(1-149). As a control for functional DNA binding, wildtype and mutated SAPla polypeptides bound the optimal Ets-1 probe with similar efficiency (Fig. 9B, lanes 12-15). As demonstrated previously, wild-type SAP1a bound the $m b-1$ promoter probe in the absence of Pax-5. None of the mutations decreased DNA binding by the mutated polypeptides alone, but the $\mathrm{K} 17 \mathrm{E} / \mathrm{P} 18 \mathrm{Q}$ mutation increased DNA binding in the absence of Pax -5 by two- to threefold relative to wild-type SAPla (Fig. 9B, lanes 5,6). Significantly, mutation of valine 68 to aspartic acid (V68D) enhanced DNA binding in ternary complexes with Pax-5(1-149) by greater than 60-fold (Fig. 9B, lane 10). Therefore, the recruitment of SAP1 a (and potentially other Ets proteins) by Pax- 5 requires an aspartic acid at the carboxyl terminus of an $\alpha$-helical motif $(\alpha 3)$ that contacts the Ets binding site (Bosselut et al. 1993; Liang et al. 1994; Werner et al. 1995; Donaldson et al. 1996).

\section{Discussion}

Here, we report that transcriptional regulation of the B-cell-specific $m b-1$ gene is mediated by the tissue-specific and temporally regulated Pax-5 protein together with more widely expressed Ets proteins. Our data represent the first biochemical evidence for interactions between a Pax family protein and other transcription factors. Sequences contacted by Pax -5 in the $m b-1$ promoter are significantly different from its consensus binding site, even when the high degree of degeneracy of the consensus is taken into account (Czerny et al. 1993). It is significant that the Pax-5 and Ets binding sites are conserved highly between the murine (Travis et al. 1991) and human (Ha et al. 1994) $m b-1$ promoter sequences (the region between -90 to -66 comprising the Pax-5 and Ets sites is identical between the two species). Therefore, we suggest that the $m b-1$ promoter has evolved a novel sequence for the assembly of ternary complexes by Pax-5.

Ternary complexes comprising Pax-5 and proteins rep- resenting three subgroups of the Ets family; Fli-1, c-Ets1 , and GABP $\alpha$ (in BTC1, BTC2, and BTC3, respectively), were detected using $\mathrm{B}$-cell nuclear extracts. Other, as yet undetected, Ets proteins may form ternary complexes with Pax-5 (c.g., our experiments suggested the heterogeneity of $\mathrm{BTCl}$ complexes, which react partially with Fli-1- or c-Ets-1-specific antisera). Two Ets family members that were recruited efficiently by recombinant Pax -5 in vitro (Net and Elk-1) were detected at only very low levels in BTCs (D. Fitzsimmons and J. Hagman, unpubl.). The lack of detection may be a technical problem. Alternatively, the recruitment of Ets proteins by Pax- 5 in B-cells may be limited to a subset of potential partners. The assembly of ternary complexes comprising Pax-5 and different Ets components in vitro suggests that the various BTCs may differentially regulate gene expression in vivo. The function of these complexes may be dictated by their Ets components that, like Pax-5, have been linked to transcriptional activation or repression in different contexts (reviewed in Wasylyk et al. 1993). Because the DNA-binding domains of other Pax family members are conserved highly, Pax proteins may regulate gene expression in other tissues by associating with Ets proteins. Future studies will address whether interactions between Pax and Ets proteins are a general mechanism for regulating gene expression in differentiating cells.

\section{Regulation of mb-1 gene expression and B-cell} differentiation by Pax-5

The importance of Pax-5:Ets binding for $m b-1$ promoter function was clearly demonstrated in transfection assays. In the current study, we showed that mutation of either the Ets (mut1) or Pax-5 (mut2) binding sites within the promoter resulted in greatly reduced transcriptional efficiency in transfected early B cells. It is unknown whether activation functions are contributed to the ternary complex by both Pax- 5 and Ets proteins or by only one of the components. Because Pax- 5 can bind the promoter independently of Ets proteins, the similar reduction in transcription observed with the loss of Ets binding (mut 1 ) or both Pax-5 and Ets binding (mut2) suggests that transcriptional activation by the complex is largely a function of Ets proteins. Many Ets proteins possess transcriptional activation domains (reviewed in Wasylyk et al. 1993). Pax-5 also possesses a potent transcriptional activation domain that is modulated by negatively acting carboxy-terminal sequences (Dörfler and Busslinger 1996). As an alternative explanation for the transfection data, binding assays suggested that stable association of the proteins with DNA is increased in the ternary complex. Therefore, Pax-5 may bind the promoter in vivo with considerably lower stability in the absence of Ets binding.

Our data confirm the hypothesis that transcriptional regulation of the B-cell-specific $m b-1$ gene is a function of at least two nuclear factors expressed only at early stages of the B lineage: Pax-5 and EBF. In earlier studies, we and others showed that a region of the $m b-1$ promoter 
A

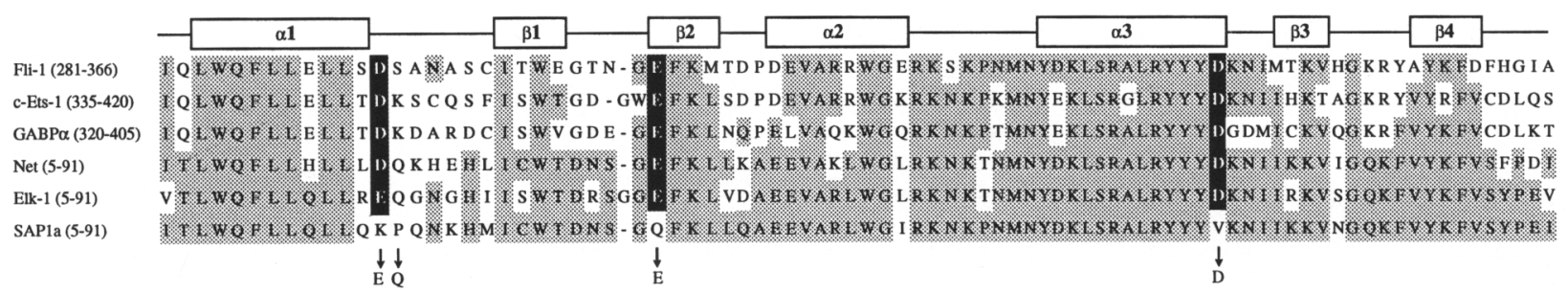

Figure 9. Mutation of sequences in the Ets domain of SAP1a allows for recruitment by Pax-5. (A) Alignment of the amino acid sequences of Ets protein DNA-binding domains (LaMarco et al. 1991; Wasylyk et al 1992; Giovane et al. 1994). Sequences are identified at left and shown relative to motifs suggested by the proposed solution structure of human Fli-1 (Liang et al. 1994). Amino acids in other Ets proteins that are identical with those of SAPla are shaded. Conserved sequences in Ets domains that are not present in SAPla are indicated by black bars. Mutations introduced into SAPla are shown below. $(B)$ DNA binding by wild-type (wt) and mutated (K17E/P18Q, Q32E, and V68D) SAPla polypeptides in the absence or presence of recombinant Pax-5(1-149). SAPla proteins were added to labeled probes at the same concentrations. $($ Left $)$ Binding of SAPla proteins to the $m b-1$ promoter probe in the absence or presence of Pax-5/1-149). Positions of Pax-5(1149), SAP1a, or ternary complexes (TC) are indicated. (Right) Binding of wild-type or mutated SAPla proteins to the optimized c-Ets-1 binding site. Exposure times for autoradiography were 3 days (left) or $12 \mathrm{hr}$ (right).
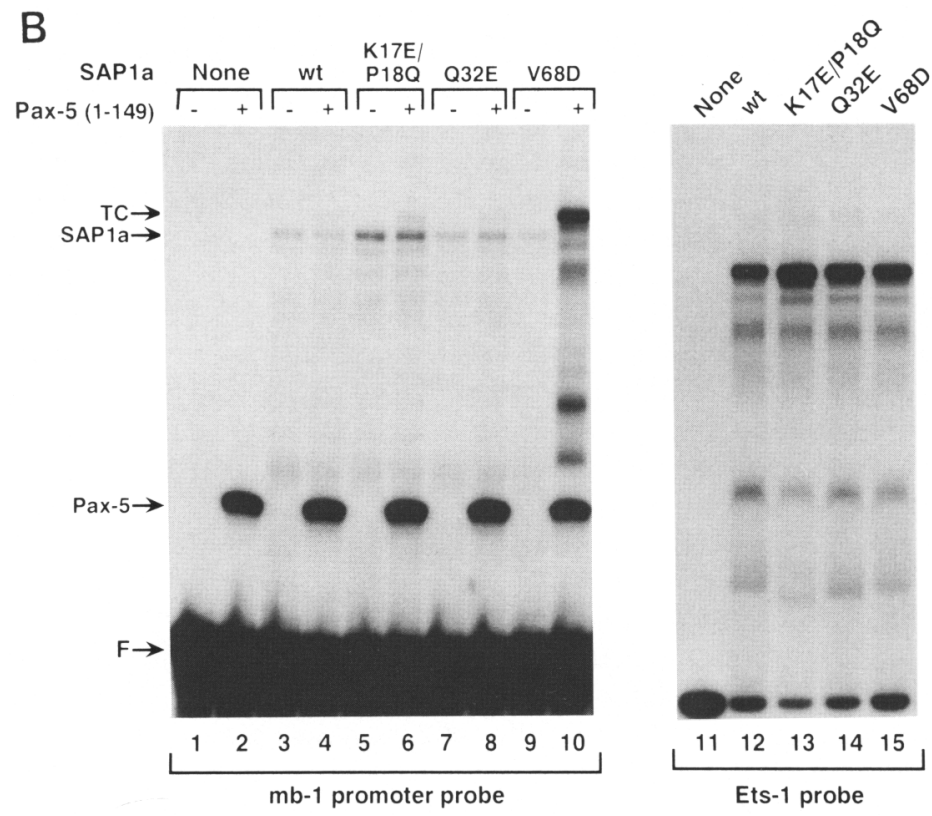

between -160 and -180 binds EBF in vitro and is important for early B-cell-specific promoter function in transfection assays (Hagman et al. 1991; Feldhaus et al. 1992). Transfection studies indicated that EBF, Pax-5, and Ets proteins function in a synergistic fashion, because clustered mutations in their binding sites (Hagman et al. 1991; this study) or deletion of promoter DNA including all of these sites (Travis et al. 1991) each resulted in similarly decreased transcription from the $m b-1$ promoter (by $\sim 80 \%$ ). In further support of this model, $m b-1$ gene expression is greatly reduced in $E B F^{-\prime-}$ (Lin and Grosschedl 1995) and pax-5 $5^{-1-}$ mutant mice (M. Busslinger, pers. comm.). Defective regulation of the $m b-1$ gene provides an explanation for the severity of the phenotype of pax-5 $5^{-1-}$ mice, because the $\operatorname{Ig} \alpha$ polypeptide is important for the display of membrane-bound immunoglobulin on the cell surface and signaling functions in early B cells (reviewed in Gold and Matsuuchi 1995).

Potential mechanisms for the recruitment of Ets proteins by Pax-5

DNA binding by Ets proteins is regulated at multiple levels. First, DNA binding is dependent upon specific nucleotide sequences. With very few exceptions, all Ets protein binding sites include the core sequence GGA. In addition, the relative ability of these sequences to serve as binding sites depends upon flanking nucleotides. Second, for less than optimal sequences, inhibitory domains within most Ets proteins limit their DNA-binding ability. To relieve the effects of inhibitory sequences and to facilitate binding to regulatory elements of target genes, it has been proposed that interactions with partner proteins modulate the functional properties of Ets proteins in vivo (Petersen et al. 1995).

One of the key outcomes of interactions with Pax- 5 is the stabilization of Ets binding to a suboptimal nucleotide sequence. The Ets binding sequence of the $m b-1$ promoter site is unusual because, prior to this study, the core sequence GGA had not been observed with an adjacent G (as GGAG) in naturally occuring Ets binding sites (Wasylyk et al. 1993). Instead, the sequence CCGGAA/T was most frequently selected in assays for optimal binding sites for c-Ets-1 (Fisher et al. 1991; Woods et al. 1992; Nye et al. 1992), Elk-1 (Treisman et al. 1992), and Net (SAP-2; Shore et al. 1996). We determined that the $\mathrm{G}-\mathrm{C}$ base-pair substitution in the $m b-1$ promoter Ets site (CCGGAG) interferes with Ets DNA binding, because mutation of the sequence CCGGAG to CCG- 
GAA allows for efficient DNA binding by Ets proteins in the absence of Pax-5 (Fig. 8). The last A-T pair of the optimized binding site (CCGGAA) is contacted by c-Ets-1 (Nye et al. 1992), although the region of the protein that interacts with this base pair is unclear. Conversely, the $\mathrm{G}$ to $\mathrm{A}$ mutation decreased Pax -5 binding by a factor of 20 , demonstrating that the $\mathrm{G}-\mathrm{C}$ pair includes important DNA contacts for Pax -5 . These data show that Pax-5 binds a nucleotide sequence flanking the Ets core that would be contacted by Ets proteins on more optimal binding sites. Because we have shown that the core sequence is essential for Ets binding, we conclude that Pax- 5 and Ets proteins bind DNA in very close proximity with one another in the ternary complex.

At another level of control, DNA binding by many Ets proteins (c.g., c-Ets-1 and Net) is negatively regulated, or repressed, by inhibitory sequences flanking the DNAbinding domain (Hagman and Grosschedl 1992; Lim et al. 1992; Nye et al. 1992; Treisman et al. 1992; Wasylyk et al 1992; Giovane et al. 1994; Jonsen et al. 1996; Lopez et al. 1994). In the presence of inhibitory sequences, c-Ets- 1 undergoes a conformational change in the DNAbound form relative to the unbound form (Wasylyk et al. 1992; Petersen et al. 1995). This alteration has been interpreted as DNA-induced allosteric unfolding of an $\alpha$-helix within the amino-terminal inhibitory region $(\mathrm{Pe}$ tersen et al. 1995). c-Ets-1 including the inhibitory sequences binds DNA with reduced affinity, but DNA binding is greatly enhanced (by 15 - to 60 -fold) when these sequences are deleted.

The interaction of Ets proteins with partner proteins has been hypothesized to mediate the derepression of DNA binding, e.g., by preventing refolding and restoration of the repressed state. In support of this model, two proteins have been shown to facilitate Ets protein DNA binding by interaction with the inhibitory sequences. Serum response factor (SRF) interacts with a subset of Ets proteins (e.g., Elk-1, SAPla and SAPlb, and Net) through the Ets B domain (Janknecht and Nordheim 1992; Janknecht et al. 1994; Shore and Sharrocks 1994). Another protein with these properties is the Runt domain factor PEBP2 $\alpha(\mathrm{CBF})$, which binds the T-cell receptor $\alpha$ and $\beta$ enhancers cooperatively with c-Ets-1 by interacting with sequences (between amino acids 123-240) that overlap with the amino-terminal inhibitory domain (Wotton et al. 1994; Giese et al. 1995). Our data suggest that interactions with Pax-5 also result in the derepression of DNA binding by Ets proteins. Deletions of inhibitory domains of Net, c-Ets-1, or Fli-1 each resulted in binding of the $m b-1$ promoter site in the absence of Pax-5 (Fig. $6 \mathrm{~A}, \mathrm{C}$, and J. Hagman, unpubl.), although not to the degree observed in the presence of Pax- 5 or with other more optimal binding sites. Therefore, we propose that the recruitment of Ets proteins by Pax-5 has at least two consequences for Ets DNA binding: derepression from the effects of inhibitory domains, and facilitation of binding to a suboptimal nucleotide sequence.

Interactions with Pax- 5 appear to be mediated by the ETS domain, because Ets polypeptides consisting of this minimal domain are recruited by the Pax -5 paired box.
However, the data are currently not sufficent to discriminate between different models for Pax-5:Ets interactions. As one possible mechanism, Pax-5 may allow for DNA binding by Ets proteins by modifying the conformation of the binding site, i.e., by inducing a specific bend in DNA (Chalepakis et al. 1994). Alternatively, protein-protcin interactions between Pax-5 and the ETS domain may stabilize binding in the absence of sufficient contacts for Ets binding alone, similar to the recruitment of Elk-l by SRF to a suboptimal site in the c-fos SRE (revicwed in Treisman 1994). In this regard, the G to A mutation, which reduces Pax- 5 binding and enhances Net binding in vitro (Fig. 8), allows for ternary complex formation in a reciprocal fashion (Net recruits Pax-5 to bind the mutated sequence). This may indicate that ternary complex formation requires that either protein make sufficient contacts to bind DNA independently of its partner, with protein-protein contacts providing the basis for cooperative interactions between the two components. Other proteins that can interact with the DNAbinding domains of Ets proteins include the basic-leucine zipper (b-Zip) protein c-Jun, which can associate with the ETS domains of c-Ets-1, Elf-1, PU.1, and Fli-1 in the absence of DNA in vitro (Bassuk and Leiden 1995). More recently, a novel b-Zip protein, MafB, was shown to interact with the ETS domain of c-Ets-1 via its basic region, resulting in the inhibition of c-Ets-1 DNA binding and of erythroid cell differentiation (Sieweke et al. 1996). In preliminary experiments, we have not detected interactions between the Pax- 5 paired box and the ETS domain of c-Ets-1 in the absence of DNA (D. Fitzsimmons, unpubl.). Studies in other laboratories have detected DNA-dependent conformational changes in Pax protcins that may be required for ternary complex formation (e.g., the paired box of Pax- 6 shifts from a relatively structureless conformation to a highly $\alpha$-helical structure upon binding DNA; Epstein et al. 1994). Therefore, amino acid contacts between Pax- 5 and Ets proteins may be available only when Pax-5 is bound to DNA.

The inability of SAPla to assemble complexes with Pax -5 on the $m b-1$ promoter in vitro defines an important amino acid for Pax-5:Ets ternary complex formation and a functional difference between the ternary complex factors Elk-1 and SAPla, which show related, but distinct DNA-binding specificities (Treisman et al. 1992; Shore and Sharrocks 1995). By itself, SAPla binds weakly to the $m b-1$ promoter sequence and does not assemble ternary complexes with Pax-5. Introduction of the V68D mutation into the ETS domain of SAPla did not affect binding in the absence of Pax-5, but the mutated SAPla polypeptides were recruited efficiently by Pax -5 . Ternary complex formation may be mediated by direct contacts between Pax-5 and the aspartic acid, which is located adjacent to the $\alpha 3$ motif that contacts the major groove of the Ets binding site (Werner et al. 1995; Donaldson et al. 1996). Alternatively, the aspartic acid of the ETS domain may allow for binding to the suboptimal sequence by contacting the DNA directly. In the latter case, Pax -5 may facilitate these additional DNA contacts through other interactions with the ETS domain. However, a re- 
cent study showed that V68 of SAP1a and D69 of Elk-1 are critical determinants of the different DNA binding specificities of these proteins (Shore et al. 1996). Intriguingly, the authors suggested that amino acids at this position are oriented away from the DNA and, therefore, modulate DNA binding through intramolecular interactions. We have not yet defined the mechanism involving this aspartic acid, but the identification of a single amino acid as crucial for recruitment by Pax- 5 divides the Ets proteins into two subclasses: those with the critical aspartic acid (e.g., Erg-1), and those with other amino acids at the same position (e.g., glutamine in Elf- 1 and lysine in Ets-4 and PU.1; Wasylyk et al. 1993; arginine in ER71 and asparagine in Pep1; Landsman and Wolffe 1995). It will be of interest to determine whether the differences detected between SAP1a and other Ets proteins reflect their potential for interactions with other proteins in tissues that do not express Pax-5. Together, our data and those of other laboratories suggest that Ets proteins expressed in multiple cell types can be utilized in a more restricted fashion by interacting with other proteins that incorporate Ets functions into cell-type-specific transcription factor complexes.

\section{Materials and methods}

Plasmids and in vitro mutagenesis

For expression of human Pax-5 in vitro, plasmid Pax-5.S1 was derived from pBLKS $+-\lambda$ P5 (kindly provided by Peter Gruss, Max-Planck-Institut für Biophysikalische Chemie, Göttingen, Germany) using PCR, oligonucleotides 5'-GAGCTCATCATGGATTTAGAGAAAAATTAC, 5'-GGGCCCGTGGCGGTCGTACGCAGT, and Pfu DNA polymerase (Stratagene, La Jolla, $\mathrm{CA}$ ), and subcloned into Bluescript KS + (Stratagene, La Jolla, CA) to make Pax-5.31. For translation of Pax-5(1-149) in vitro, plasmid $\triangle$ Pax-5.4 was made similarly using oligonucleotides 5'-GAGCTCATCATGGATTTAGAGAAAAATTAC and 5'-GGCGGCAAGCTTATTGGTTGGGTGGCTGCT.

PCR mutagenesis (Merino et al. 1992) was used to introduce mutations into $m b-1$ promoter sequences in the plasmid pMbI$\mathrm{BH}$ (Travis et al. 1991). The mutl promoter was constructed by PCR amplification of pMbl-BH using 5'-ACCCGGGGATCCATGGTGATGAACC $\left(m b-1\right.$ promoter $5^{\prime}$ end $)$ and $5^{\prime}$-CGTGCCTTAGATGGGCTCCAGTGGC (mut l, antisense), and 5'. TACGCCAAGCTTGCAGGAGGAGAGGC $(m b-1$ promoter 3' end) and 5'-CCATCTAAGGCACGGCTGAACAGGA (mutl, sense). The two resulting fragments were gel purified, mixed, and reamplified with the $m b-1$ promoter $5^{\prime}$ and $3^{\prime}$ end primers. The mut 2 promoter was made by amplification of pMbI-BH with the $5^{\prime}$ end primer and $5^{\prime}$-GGCTCAATTTGCCCTTACTCCTGGCCC (mut2, antisense), and with the $3^{\prime}$ end primer and 5'-AGGGCAAATTGAGCCCATCTCCGGCAC (mut2, sense). Completed promoter fragments were cut with $M s c I$ and Asp 718 and mutated 139-bp fragments were introduced into pMbI-BH. BamHI-HindIII fragments from the resulting plasmids (mut 1 and mut2) were filled in with Klenow fragment and ligated into the blunted Sall site of T $\beta P y$ Igenerated from $\beta P y$ |Grosschedl and Baltimore 1985) by the addition of three tandem copies of a 237-bp SV40 polyadenylation signal sequence (Maxwell et al. 1989) at the Sall site). For insertion of both mut 1 and mut 2 sequences in the $m b-1$ promoter, the mut 2 plasmid was amplified using the $5^{\prime} \mathrm{mb}-1$ promoter primer and $5^{\prime}$ -
CGTGCCTTAGATGGGCTCAATTTGC $/$ mut $1+$ mut2, antisensel, or with the $3^{\prime} m b-1$ promoter and mutl sense primers, and processed as described for single mutations.

Plasmids for expression of full-length Net, Elk-1, and SAPla were described previously. Plasmids for expression of carboxyterminal deletions of Net were made by PCR of Net cDNA sequences with a single $5^{\prime}$ end primer and different 3 'end primers, followed by digestion with $\mathrm{KpnI}$ and insertion of fragments into the KpnI site of plasmid pKOZ1 (Giovane et al. 1994). The $5^{\prime}$ end primer was $5^{\prime}$-CGGGGTACCCCGATGGAGAGTGCAATCACGCTGTG. 3'end primers were 5'-CGGGGTACCCCGTCAAGATGAGGCCAGGAAAGCGGAT, Net(1-342); $5^{\prime}$-CGGGGTACCCCGTCAAGCGGTCTCGGATGTGGAAGG, Net(1-219); 5'-CGGGGTACCCCGTCACTGCAGGGAGTTGATGGTGAA, Net(1-209); 5'-CGGGGTACCCCGTCAACTTTTGAGGGAGGACAAGCCG, Net(1-132); or 5'-CGGGGTACCCCGTCAATCCGGGAAAGAGACGAACTTGT, Net(1-89). The plasmids for expression of the DNA-binding domains of murine c-Ets-1 (amino acids 333-420) or murine Fli-1 (amino acids 279366) were made by PCR of SKcetswt (Hagman and Grosschedl 1992) using primers 5'-ACCATGGGGCCGATCCAGCTGTGGCAG and 5'-CTACTAGCTCTGCAGGTCGCACACAAA, or of flipGEX3X (kindly provided by Stephen Smale, Howard Hughes Medical Institute, UCLA School of Medicine, Los Angeles, CA using primers 5 -ACCATGGGGCAGATCCAGCTGTGGCAG and 5'-CTACTAGGCAATGCCATGGAAGTCAAA, respectively, and cloning into the Ecl136II site of Bluescript KS +

The human SAPla cDNA was subcloned from pT7SAP1a (modified from Dalton and Treisman 1992) to make KOZhSAPla and mutated to include amino acid sequences of Elk-1 using PCR mutagenesis. Two fragments were generated for each mutation using PCR as follows: K17E/P18Q, 5'-TAATACGACTCACTATAGGG (T7 promoter) and 5'-CTGCTCTTGCAGGAGCTGAAGAAG (SAPla-mut l, antisense), and 5'-TGCAAGAGCAGCAGAACAAGCACATGAT (SAPla-mutl sense) and $5^{\prime}$-GGTTTATCTTTCCCTCCATTCTCC (SAPla antisense); Q32E, T7 promoter primer and 5'-GAATTCCCCATCATTAGAGGTCC (SAPla-mut2, antisense), and 5'-TGGGGAATTCAAGCTTTTGCAGGCAGA (SAPla-mut2, sense) and SAPla antisense primers; V68D, T7 promoter primer and 5'-CTTGTCATAATAGTATCTGAGGGC (SAPla-mut3, antisense), and 5'-TTATGACAAGAATATCATCAAAAAAGTG (SAPla-mut3, sense) and SAPla antisense primers. Amplified fragments were combined using PCR, and restricted with XhoI and PmeI to replace sequences in KOZ-hSAPla.

\section{Nuclear extracts and transcription/translation in vitro}

Nuclear extracts were prepared as described previously (Hagman et al.1995). Transcription of plasmid DNA using T7 RNA polymerase (Promega, Madison, WI), purification of RNA, and translation in vitro using rabbit reticulocyte lysate (Promega) were described previously (Hagman and Grosschedl 1992). Pax5.S1 was linearized with restriction enzymes to transcribe RNA encoding full-length 1-391 (HindIII), 1-318 (AfIIII), 1-281 (MscI), 1-233 (PvuII), or 1-175 (EagI). $\Delta$ Pax-5.4 was linearized with HindIII. All Net, SAPla, and Elk-1 plasmids were linearized with XbaI.

\section{DNA probes, competitors, and EMSAs}

Double-stranded oligonucleotides were annealed and labeled with ${ }^{32} \mathrm{P}$ using Klenow fragment and $\alpha^{32} \mathrm{P}$-dCTP as described previously (Hagman et al. 1991). The wild-type $m b-1$ promoter probe sequence was 5'-TCGAAGGGCCACTGGAGCCCATCTCCGGCACGGC and 5'-TCGAGCCGTGCCGGAGATGGGCTCCAGTGGCCCT. Oligonucleotides comprising the $\mathrm{G}$ to 
A mutation probe were identical with the wild-type sequence, except that the underlined bases were synthesized as $\mathrm{T}$ and $\mathrm{A}$, respectively. Probes with mutations in Pax-5 or Ets binding sites were synthesized as shown in Figure 6A. The CD19 promoter Pax-5 binding site (CD19-1; Kozmik et al. 1992), wildtype and mutated (single $\mathrm{C}$ to A mutation) sea urchin histone H2A-2.2 promoter Pax- 5 binding sites (Barberis et al. 1990), EBF binding site (Hagman et al. 1991), and the optimized c-Ets-1 binding site, or Ets-1 probe (Giovane et al. 1994), were described previously. Relative levels of DNA binding were estimated using a Molecular Dynamics PhosphorImager (Sunnyvale, CA).

EMSA was performed as described previously (Hagman et al. 1991), except that poly[d(I-C)].poly[d(I-C)] and Nonidet-P40 were included at $30 \mu \mathrm{g} / \mathrm{ml}$ and $0.1 \%$, respectively. For immunodetection of DNA binding proteins, antisera were incubated with nuclear extracts $15 \mathrm{~min}$ at $4^{\circ} \mathrm{C}$ prior to addition of probe DNA. Antisera recognizing either the paired box or carboxyterminal peptide sequences of Pax-5, c-Ets-1 or PU.1, and $\mathrm{GABP} \alpha$ or $\mathrm{CABP} \beta$ were generously provided by Meinrad Busslinger (Research Institute of Molecular Pathology, Vienna, Austria), Richard Maki (La Jolla Cancer Research Center, La Jolla, CA), and Tom Brown (Pfizer Central Research, Groton, CT), respectively. Anti-Fli-1 and anti-SRF purified polyclonal IgG fractions were obtained from Santa Cruz Biotech (Santa Cruz, CA). Anti-c-Jun/AP-1 antisera was obtained from Oncogene Science (Uniondale, NY).

Transfection of pre-B cells, probe preparation by biotin capture, and $S 1$ nuclease protection assays

PD36 pre-B cells were maintained in culture and transfected with plasmid DNA using the DEAE-dextran method, and total cellular RNA was prepared $48 \mathrm{hr}$ post-transfection as described previously (Hagman et al. 1991). An S1 nuclease protection assay was modified from the method of Grosschedl and Baltimore (1985). ${ }^{32} \mathrm{P}$-labeled singled-stranded antisense DNA probes were prepared by separation from unlabeled biotinylated sense strand using Streptavidin Dynabeads (Dynal Inc., Great Neck, NY). For the $m b-1$ promoter-specific probe, a 446-bp fragment was amplified from TM $\mathrm{TPy}$ using PCR, the $m b-1$ promoter specific oligonucleotide $5^{\prime}$-biotin-ATCCTTTCTCAGGGATCAGTGGT and the murine $\beta$-globin exon 2 sequence $5^{\prime}$-GATCCACATGCAGCTTGTCACAG. For the murine histone $\mathrm{H} 4$ reference probe, oligonucleotides 5'-biotin-CGGATAATTTAGAAAGGTTC and 5'-CGGAGATGCGCTTGACCCCA were used to amplify 265 bp from the plasmid pBR-H4 (Grosschedl and Baltimore 1985). DNA fragments were labeled using $\gamma^{32} \mathrm{P}$ ATP $16000 \mathrm{Ci} / \mathrm{mmole}$, DuPont/New England Nuclear, Boston, MA) and T4 polynucleotide kinase (New England Biolabs, Beverly, $\mathrm{MA}$ ), precipitated from $2.5 \mathrm{M} \mathrm{NH}_{4} \mathrm{OAc}$ to remove free ATP, and redissolved in $10 \mu \mathrm{l} 50 \mathrm{~mm}$ Tris- $\mathrm{HCl}, \mathrm{pH} 8 / 0.1 \mathrm{~mm}$ EDTA (hiTE). $10 \mu \mathrm{l}$ of deionized formamide were added and heated $5 \mathrm{~min}$ at $95^{\circ} \mathrm{C}$. Denatured probe DNA was chilled on ice, brought to 200 $\mu \mathrm{l}$ with hiTE, and $20 \mu \mathrm{l}$ of suspended Strepavidin Dynabeads (washed $4 \times 1$ vol. hiTE, preincubated $10 \mathrm{~min}$ with $10 \mathrm{mg} / \mathrm{ml}$ poly[d(I-C)]/poly[d(I-C)], and washed $2 \times$ with hiTE) were added and incubated $5 \mathrm{~min}$ with shaking at room temperature. Supernatant was recovered from beads following centrifugation. Probe DNA was hybridized with total cellular RNA, digested with S1 nuclease (60U), and analyzed using denaturing polyacrylamide gel electrophoresis as described previously /Travis et al. 1991). Relative levels of protected transcripts were measured using the PhosphorImager.

\section{Acknowledgments}

We are greatly indebted to Peter Gruss for providing the Pax-5 cDNA clone, and Richard Maki, Meinrad Busslinger, and Tom
Brown for their generous gifts of antisera. We also thank Gary Johnson, Gordon Keller, and Neil Kabrun for reviewing this manuscript, Arthur Gutierrez-Hartmann and Rudolf Grosschedl for helpful discussions, Shadrach Eubanks and Darrin Eisman of the Molecular Resource Center of NJCIRM for oligonucleotide synthesis, and Leigh Landskroner for technical illustration. W.W. is supported by National Institutes of Health Training Grant AI00048. This work was supported in part by grants to J.H. from the Milheim Foundation for Cancer Research and the National Institutes of Health (PO1 AI22295). S.-M.M. is a recipient of a Ligue Nationale Francaise contre le Cancer, fcllowship. B.W. thanks the following for funding: the Centre National de la Recherche Scientifique, the Insitut National de la Santé et de la Recherche Médicale, the Centre Hospitalier Universitaire Régional, the Association pour la Recherche sur la Cancer, the Fondation pour la Recherche Médicale, the Ligue Nationale Francaise contre le Cancer, the Ligue Régionale (BasRhin-Legs Meyer and Haut Rhin) contre le Cancer and the Bioavenir Program (Ministère de l'Éducation Nationale, de l'Enseignment Supérieur, de la Recherche et de l'Insertion Professionelle et Rhône Poulenc Rorer).

The publication costs of this article were defrayed in part by payment of page charges. This article must therefore be hereby marked "advertisement" in accordance with 18 USC section 1734 solely to indicate this fact.

\section{References}

Adams, B., P. Dorfler, A. Aguzzi, Z. Kozmik, P. Urbanek, I. Maurer-Fogy, and M. Busslinger. 1992. Pax-5 encodes the transcription factor BSAP and is expressed in B-lymphocytes, the developing CNS, and adult testis. Genes \& Dev. 6: $1589-1607$.

Asano, M. and P. Gruss. 1992. Pax-5 is expressed at the midbrain-hindbrain boundary during mouse development. Mech. Dev. 39: 29-39.

Baldwin, C.T., C.F. Hoth, J.A. Amos, E.O. daSilva, and A. Milunsky. 1992. An exonic mutation in the HuP2 paired domain gene causes Waardenburg's syndrome. Nature 355: 637-638.

Baberis, A., K. Widenhorn, L. Vitelli, and M. Busslinger. 1990. A novel B-cell lineage-specific transcription factor present at carly but not late states of differentiation. Genes \& Dev. 22: $37-43$.

Bassuk, A.G. and J.M. Leiden. 1995. A direct physical association between ETS and AP-1 transcription factors in normal human T cells. Immunity 3: 223-237.

Bosselut, R., J. Levin, E. Adjadj, and J. Ghysdael. 1993. A single amino-acid substitution in the Ets domain alters core DNA binding specificity of Etsl to that of the related transcription factors Elf1 and E74. Nucleic Acids Res. 21: 5184-5191.

Brown, T.A. and S.L. McKnight. 1992. Specificities of proteinprotein and protein-DNA interaction of GABP $\alpha$ and two newly defined ets-related proteins. Genes \& Dev. 6: 25022512.

Busslinger, M. and P. Urbánek. 1995. The role of BSAP (Pax-5) in B-cell development. Curr. Opin. Genet. Dev. 5: 595-601.

Chalepakis, G., R. Fritsch, H. Fickenscher, U. Deutsch, M. Goulding, and P. Gruss. 1991. The molecular basis of the undulated/Pax-1 mutation. Cell 66: 873-884.

Chalepakis, G., I. Wiinholds, and P. Gruss. 1994. Pax-3-DNA interation: Flexibility in the DNA binding and induction of DNA conformational changes by paired domains. Nucleic Acids Res. 22: 3131-3137.

Czerny, T., G. Schaffner, and M. Busslinger. 1993. DNA se- 
quence recognition by Pax proteins: Bipartite structure of the paired domain and its binding site. Genes \& Dev. 7: 2048-2061.

Dalton, S. and R. Treisman. 1992. Characterization of SAP-1, a protein recruited by serum response factor to the $\mathrm{c}$-fos serum response element. Cell 68: 597-612.

Donaldson, L.W., J.M. Petersen, B.J. Graves, and L.P. McIntosh. 1996. Solution structure of the ETS domain from murine Ets-1: A winged helix-turn-helix DNA binding motif. $E M B O$ I. 15: 125-134.

Dörfler, P. and M. Busslinger. 1996. C-terminal activating and inhibitory domains determine the transactivation potentional of BSAP (Pax-5), Pax-2, and Pax-8. EMBO I. 15: 19711982.

Engel, P., L.-J. Zhou, D.C. Ord, S. Sato, B. Koller, and T.F. Tedder. 1995. Abnormal B-lymphocyte development, activation, and differentiation in mice that lack or overexpress the CD19 signal transduction molecule. Immunity 3: 39-50.

Epstein, D.J., M. Vekemans, and P. Gros. 1991. Splotch $\left(\mathrm{Sp}^{2 \mathrm{H}}\right)$, a mutation affecting development of the mouse neural tube, shows a deletion within the paired homeodomain of Pax-3. Cell 57: 767-774.

Epstein, J., J. Cai, T. Glaser, L. Jepeal, and R. Maas. 1994. Identification of a Pax paired domain recognition sequence and evidence for DNA-dependent conformational changes. I. Biol. Chem. 269: 8355-8361.

Feldhaus, A., D. Mbangkollo, K. Arvin, C. Klug, and H. Singh. 1992. BlyF, a novel cell-type- and stage-specific regulator of the B-lymphocyte gene mb-1. Mol. Cell. Biol. 12: 11261133.

Fisher, F.J., G. Mavrothalassitis, A. Kondoh, and T.S. Papas. 1991. High affinity DNA-protein interactions of the cellular ETS1 protein: The determination of the ETS binding motif. Oncogene 6: 2249-2254.

Giese, K., C. Kingsley, J.R. Kirshner, and R. Grosschedl. 1995. Assembly and function of a TCR $\alpha$ enhancer complex is dependent on LEF-1-induced DNA bending and multiple protein-protein interactions. Genes \& Dev. 9: 995-1008.

Giovane, A., A. Pintzas, S.-M. Maira, P. Sobieszczuk, and B. Wasylyk. 1994. Net, a new ets transcription factor that is activated by Ras. Genes \& Dev. 8: 1502-1513.

Gold, M.R. and L. Matsuuchi. 1995. Signal transduction by the antigen receptors of $\mathrm{B}$ and $\mathrm{T}$ lymphocytes. Int. Rev. Cytol. 157: $181-276$.

Goulding, M.D., G. Chalepakis, U. Deutsch, J.R. Ersellius, and P. Gruss. 1991. Pax-3, a novel murine DNA binding protein expressed during early neurogenesis. EMBO I. 10: 11351147.

Grosschedl, R. and D. Baltimore. 1985. Cell-type specificity of immunoglobulin gene expression is regulated by at least three DNA sequence elements. Cell 41: 885-897.

Ha, H. B.L. Barnoski, L. Sun, B.S. Emanuel, and P.D. Burrows. 1994. Structure, chromosomal localization, and methylation pattern of the human mb-1 gene. I. Immunol. 152: 57495757.

Hagman, J. and R. Grosschedl. 1992. An inhibitory carboxylterminal domain in Ets-1 and Ets- 2 mediates differential binding of ETS family factors to promoter sequences of the mb-1 gene. Proc. Natl. Acad. Sci. 89: 8889-8893.

Hagman, J., A. Travis, and R. Grosschedl. 1991. A novel lineagespecific nuclear factor regulates $\mathrm{mb}-\mathrm{l}$ gene transcription at the early stages of B-cell differentiation. EMBO I. 10: 34093417.

Halder, G., P. Callaerts, and W.J. Gehring. 1995. Induction of ectopic eyes by targeted expression of the eyeless gene in Drosophila. Science 267: 2788-1792.
Hill, R.E., J. Favor, B.L.M. Hogan, C.C.T. Ton, G.F. Saunders, I.M. Hanson, J. Prosser, T. Jordan, N.D. Hastie, and V. van Heyningen. 1991. Mouse small eye results from mutations in a paired-like homeobox-containing gene. Nature 354: 522-525.

Hipskind, R.A., V.N. Rao, C.G. Mueller, E.S. Reddy, and A Nordheim. 1991. Ets-related protein Elk-1 is homologous to the c-fos regulatory factor p62TCF. Nature 354: 531-534.

Janknecht, R. and A. Nordheim. 1992. Elk-1 domains required for direct and SRF-assisted DNA-binding. Nucleic Acids Res. 20: 3317-3324.

Janknecht, R., R. Zinck, W.H. Ernst, and A. Nordheim. 1994. Functional dissection of the transcription factor Elk-1. Oncogene 9: 1273-1278.

Jonsen, M.D., J.M. Petersen, Q.-P. Xu, and B.J. Graves. 1996. Characterization of the cooperative function of inhibitory sequences in Ets-1. Mol. Cell. Biol. 16: 2065-2073.

Jordan, T., I.M. Hanson, D. Zaletayev, S. Hodgson, J. Prosser, A. Seawright, N.D. Hastie, and V. van Heyningen. 1992. The human PAX6 gene is mutated in two patients with aniridia. Nature Genetics 1: 328-332.

Karim, F.D., L.D. Urness, C.S. Thummel, M.J. Klemsz, S.R. McKercher, A. Celada, C. Van Beveren, R.A. Maki, C.V. Gunther, J.A. Nye, and B.J. Graves. 1990. The ETS-domain: A new DNA-binding motif that recognizes a purine-rich core DNA sequence. Genes \& Dev. 4: 1451-1453.

Kozmik, Z., S. Wang, P. Dorfler, B. Adams, and M. Busslinger. 1992. The promoter of the CD19 gene is a target for the B-cell-specific transcription factor BSAP. Mol. Cell. Biol. 12: $2662-2672$.

LaMarco, K.L., C.C. Thompson, B.P. Byers, E.M. Walton, and S.L. McKnight. 1991. Identification of Ets- and Notch-related subunits in GA binding protein. Science 253: 789-792.

Landsman, D., and A.P. Wolffe. 1995. Common sequence and structural features in the heat-shock factor and Ets families of DNA-binding proteins. Trends Biochem. Sci. 20: $225-$ 226.

Liang, H., X. Mao, E.T. Olejniczak, D.G. Nettesheim, L. Yu, R.P. Meadows, C.B. Thompson, and S.W. Fesik. 1994. Solution structure of the ets domain of Fli-1 when bound to DNA. Nature Struct. Biol. 1: 871-876.

Liao, F., S. Giannini, and B. Brishtein. 1992. A nuclear DNAbinding protein expressed during early stages of B-cell differentiation interacts with diverse segments within and 3 ' of the Ig H chain gene cluster. J. Immunol. 148: 2909-2917.

Liao, F., B.K. Birshtein, M. Busslinger, and P. Rothman. 1994 The transcription factor BSAP (NF-HB) is essential for im munoglobulin germ-line $\epsilon$ transcription. I. Immunol 152: 2904-2911.

Lim, F., N. Kraut, J. Frampton, and T. Graf. 1992. DNA binding by c-Ets-1, but not v-Ets, is repressed by an intramolecular mechanism. EMBO /. 11: 643-652.

Lin, H. and R. Grosschedl. 1995. Failure of B-cell differentiation in mice lacking the transcription factor EBF. Nature 376: 263-267.

Lopez, M., P. Oettgen, Y. Akbarali, U. Dendorfer, and T. Libermann. 1994. ERP, a new member of the ets transcription factor/oncoprotein family: Cloning, characterization, and differential expression during B-lymphocyte development. Mol. Cell. Biol. 14: 3292-3309.

Maxwell, I., G. Harrison, W. Wood, and F. Maxwell. 1989. A DNA cassette containing a trimerized SV 40 polyadenylation signal which efficiently blocks spurious plasmid-initiated transcription. BioTechniques 7: 276-280.

Merino, E., J. Osuna, F. Bolivar, and X. Saberon. 1992. A general, PCR-based method for single or combinatorial oligonucle- 
otide-directed mutagenesis on pUC/M13 vectors. BioTechniques 12: 508-510.

Neurath, M.F., W. Strober, and Y. Wakatsuki. 1994. The murine immunoglobulin $3^{\prime} \alpha$ enhancer is a target site with repressor function for the B-cell lineage-specific transcription factor BSAP (NF-HB, S $\alpha-B P)$. I. Immunol. 153: 730-742.

Neurath, M.F., E.E. Max, and W. Strober. 1995. Pax5 (BSAP) regulates the murine immunoglobulin $3^{\prime} \alpha$ enhancer by suppressing binding of $N F-\alpha \mathrm{P}$, a protein that controls heavy chain transcription. Proc. Natl. Acad. Sci. 92: 5336-5340.

Nye, J.A., J.M. Petersen, C.V. Gunther, M.D. Jonsen, and B.J. Graves. 1992. Interaction of murine Ets-1 with GGA-binding sites establishes the ETS domain as a new DNA-binding motif. Genes \& Dev. 6: 975-990.

Petersen, J.M., J.J. Skalicky, L.W. Donaldson, L.P. McIntosh, T. Alber, and B.J. Graves. 1995. Modulation of transcription factor Ets-1 DNA binding: DNA-induced unfolding of an $\alpha$ helix. Science 269: 1866-1869.

Price, M.A., A.E. Rogers, and R. Treisman. 1995. Comparative analysis of the ternary complex factors Elk-1, SAPla, and SAP-2(ERP/NET). EMBO f. 14: 2589-2601.

Rickert, R.C., K. Rajewsky, and J. Roes. 1995. Impairment of T-cell-dependent B-cell responses and B-1 cell development in CD19-deficient mice. Nature 376: 352-355.

Shore, P. and A.D. Sharrocks. 1994. The transcription factors Elk-1 and serum response factor interact by direct proteinprotein contacts mediated by a short region of Elk-1. Mol. Cell. Biol. 14: 3283-3291.

- 1995. The ETS-domain transcription factors Elk-1 and SAP-1 exhibit differential DNA binding specificities. $\mathrm{Nu}$ cleic Acids Res. 23: 4698-4706.

Shore, P., A.J. Whitmarsh, R. Bhaskaran, R.J. Davis, J.P. Waltho, and A.D. Sharrocks. 1996. Determinants of DNA-binding specificity of ETS-domain transcription factors. Mol. Cell. Biol. 16: 3338-3349.

Siewecke, M.H., H. Tekotte, J. Frampton, and T. Graf. 1996. MafB is an interaction partner and repressor of Ets- 1 that inhibits erythroid differentiation. Cell 85: 49-60.

Singh, M. and B. Birshtein. 1993. NF-HB is a repressor of the murine immunoglobulin heavy-chain $3^{\prime} \alpha$ enhancer at early stages of B-cell differentiation. Mol. Cell. Biol. 13:36113622 .

Tassabehii, M., A.P. Read, V.E. Newton, R. Harris, R. Balling, P. Gruss, and T. Strachan. 1992. Waardenburg's syndrome pateints have mutations in the human homologue of the Pax-3 paired-box gene. Nature 355: 635-636.

Thompson, C.C., T.A. Brown, and S.L. McKnight. 1991. Convergence of Ets- and notch-related structural motifs in a heteromeric DNA binding complex. Science 253: 762-768.

Ton, C.C.T., H. Hirvonen, H. Miwa, M.M. Weil, P. Monaghan, T. Jordan, V. van Heyningen, N.D. Hastie, H. Miiers-Heijboer, M. Dreschler, B. Royer-Pokora, F. Collins, A. Swaroop, L.C. Strong, and G.F. Saunders. 1991. Positional cloning and characterization of a paired-box- and homeobox-containing gene from the aniridia region. Cell 57: 1059-1074.

Travis, A., J. Hagman, and R. Grosschedl. 1991. Heterogeneously initiated transcription from the pre-B- and B-cellspecific mb-1 promoter: Analysis of the requirement for upstream factor-binding sites and initiation site sequences. Mol. Cell. Biol. 11: 5756-5755.

Treisman, J., E. Harris, and C. Desplan. 1991. The paired-box encodes a second DNA-binding domain in the Paircd-homeo-domain protein. Genes \& Dev. 5: 594-604.

Treisman, R. 1994. Ternary complex factors: Growth factor reg ulated transcription factors. Curr. Op. Genet. Develop. 4: 96-101.
Treisman, R., R. Marais, and J. Wynne. 1992. Spatial flexibility in ternary complexes between SRF and its accessory proteins. EMBO \%. 11: 4631-4640.

Urbánek, P., Z.-Q. Wang, I. Fetka, E.F. Wagner, and M. Busslinger. 1994. Complete block of early B-cell differentiation and altered patterning of the posterior midbrain in mice lacking Pax5/BSAP. Cell 79: 901-912.

Wallin, J., H. Eibel, A. Neubuser, J. Wilting, H. Koseki, and R. Balling. 1996. Paxl is expressed during development of the thymus epithelium and is required for normal T-cell maturation. Development 122: 23-30.

Walther, C., J.L. Guenet, D. Simon, U. Deutsch, B. Jostes, M.D. Goulding, D. Plachov, R. Balling, and P. Gruss. 1991. Pax: A murine multigenc family of paired-box-containing genes. Genomics 11: 424-434.

Wasylyk, B., S.L. Hahn, and A. Giovane. 1993. The Ets family of transcription factors. Eur. I. Biochem. 211: 7-18.

Wasylyk, C., J.-P. Kerckaert, and B. Wasylyk. 1992. A novel modulator domain of Ets transcription factors. Genes \& Dev. 6: 965-974.

Waters, S., K. Saikh, and J. Stavnezer. 1989. A B-cell-specific nuclear protein that binds to DNA sites $5^{\prime}$ to Ig $S \alpha$ tandem repeats is regulated during differentiation. Mol. Cell. Biol. 9: 5594-5601.

Werner, M.H., G.M. Clore, C.L. Fisher, R.J. Fisher, L. Trinh, J. Shiloach, A.M. Gronenborn. 1995. The solution structure of the human ETS1-DNA complex reveals a novel mode of binding and true side chain intercalation. Cell 83: 761-771.

Woods, D.B., J. Ghysdacl, and M.J. Owen. 1992. Identification of nucleotide preferences in DNA sequences recognized specifically by c-Ets-1 protein. Nucleic Acids Res. 20: 699-704.

Wotton, D., J. Ghysdael, S. Wang, N.A. Speck, and M.J. Owen. 1994. Cooperative binding of Ets-1 and core binding factor to DNA. Mol. Cell. Biol. 14: 840-850.

$\mathrm{Xu}$, M. and J. Stavnezer. 1992. Regulation of transcription of immunoglobulin germ-line $\gamma 1$ RNA: Analysis of the promoter/enhancer. EMBO f. 11: 145-155. 


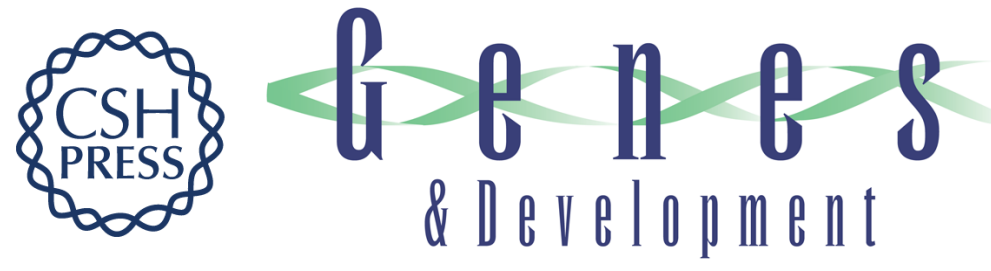

\section{Pax-5 (BSAP) recruits Ets proto-oncogene family proteins to form functional ternary complexes on a B-cell-specific promoter.}

D Fitzsimmons, W Hodsdon, W Wheat, et al.

Genes Dev. 1996, 10:

Access the most recent version at doi:10.1101/gad.10.17.2198

References This article cites 72 articles, 29 of which can be accessed free at:

http://genesdev.cshlp.org/content/10/17/2198.full.html\#ref-list-1

License

Email Alerting

Receive free email alerts when new articles cite this article - sign up in the box at the top

Service right corner of the article or click here.

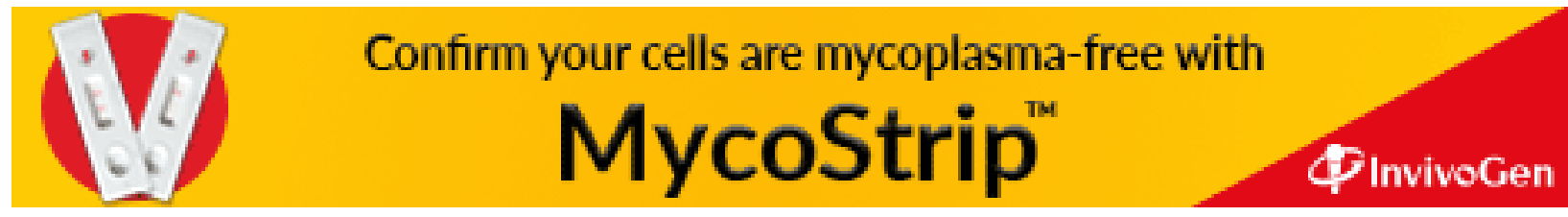

